\title{
DO VICTORIES AND LOSSES MATTER? EFFECTS OF FOOTBALL ON LIFE SATISFACTION
}

\author{
Radek Janhuba
}

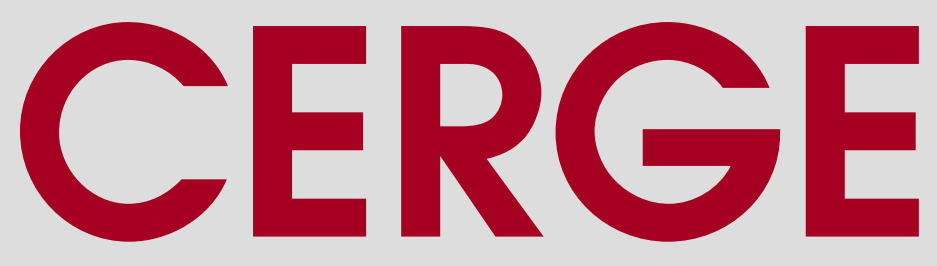

\section{Charles University}

Centerfor Economic Research and Graduate Education

Academy of Sciences of the Czech Republic

Ec onomic Institute 


\section{Working Paper Series 579 (ISSN 1211-3298)}

\section{Do Victories and Losses Matter? Effects of Football on Life Satisfaction}

Radek Janhuba

CERGE-EI

Prague, December 2016 
ISBN 978-80-7343-386-4 (Univerzita Karlova, Centrum pro ekonomický výzkum a doktorské studium)

ISBN 978-80-7344-408-2 (Národohospodářský ústav AV ČR, v. v. i.) 


\title{
Do Victories and Losses Matter? Effects of Football on Life Satisfaction*
}

\author{
Radek Janhuba ${ }^{\dagger}(\mathrm{CERGE-EI})^{\ddagger}$
}

December 2016

\begin{abstract}
Every week during the autumn season, millions of Americans attend football games and even more watch the sport on TV. In addition to generating entertainment revenues, previous research has also shown that sports events lead to changes in emotions in minds of fans. This study examines whether sports influence the subjective well-being of the population. Using data from the Behavioral Risk Factor Surveillance System (BRFSS), an ordered logit model estimates effects of a local college football team's results on the life satisfaction of local citizens. The analysis suggests that unexpected wins have positive effects on life satisfaction. Surprisingly, no effect is found for cases of unexpected losses or outcomes which can not be labeled as surprising based on the pre-game betting market.
\end{abstract}

JEL codes: I18, Z29, C25

Keywords: Life Satisfaction, Sports, Football

*This study was supported by Charles University, GAUK project No. 162415, and with institutional support RVO 67985998 from the Czech Academy of Sciences. I would like to thank Randall Filer, Jan Hanousek, Brad Humphreys, Stepan Jurajda, Neil Metz, Nikolas Mittag, Nicholas Watanabe, participants in the 2015 MVEA Kansas City and 2016 YEM Brno conferences, and participants in a CERGE-EI Brownbag and a WVU Research seminars for helpful comments and suggestions. All remaining errors are my own.

${ }^{\dagger}$ Email: radek.janhuba@cerge-ei.cz

${ }^{\ddagger}$ CERGE-EI, a joint workplace of Charles University and the Economics Institute of the Czech Academy of Sciences, Politickych veznu 7, 11121 Prague, Czech Republic. 


\section{Introduction}

Every week during the autumn season, millions of Americans attend football games of various levels, and tens of millions watch the sport on TV. ${ }^{1}$ In addition to generating billions of dollars as an entertainment industry, sports are unique in terms of the psychological processes they cause in the minds of fans. Previous research has found that being a sports fan is associated with one's emotions (Kerr et al., 2005; Jones et al., 2012) and can also lead to increases in criminal behavior (Card \& Dahl, 2011; Rees \& Schnepel, 2009).

This study examines the relationship between college football results and selfreported life satisfaction. The life satisfaction measure is part of a more general class of measures which are labeled as subjective well-being (henceforth SWB). ${ }^{2}$

The study focuses on results from American college football, which has an extremely strong fan base. ${ }^{3}$ Previous research has shown that sports teams, and football teams in particular, do not seem to create tangible economic benefits in their respective geographic areas (Coates \& Humphreys, 2008). However, they still attract massive public subsidies, mostly in the form of financing of new stadiums. Arguably, this may indicate some form of intangible benefits being created by sports teams. The specific form of implicit benefits we examine is the effect on SWB in the population.

\footnotetext{
${ }^{1}$ Note that throughout this study, the word football indicates specifically American football. When needed, the standard, European football, is referred to as soccer (derived from its full name association football).

${ }^{2} \mathrm{SWB}$ measures have recently found their way into economics from other disciplines and present an alternative way of measuring people's well-being. They have lately also been adopted as objectives of governmental policies (Diener et al., 2013).

${ }^{3}$ Market research for 2012 estimated that $43 \%$ of the US population followed college football. Source: http://sportsaffiliates. learfieldsports.com/files/2012/11/College-vs.-Pro. pdf
} 
Although some research analyzing effects of sports events on life satisfaction has been conducted (see Section 2.2 for an overview), there are two distinctions which make our approach novel and likely more generalizable. First, in contrast to previous studies concentrating on one-off, large-scale tournaments, our study seeks to identify the connection on a dataset utilizing regular weekly games. This eliminates the possibility of a spurious one-time effect that may have taken place around tournaments examined in previous studies. To our knowledge, this study is the first to examine such relationship.

Second, due to limited data availability, previous work examining the effects of sports concentrated on data from metropolitan areas. Utilizing data from Facebook likes, the unique methodology of this paper allows us to use data from non-urban areas as well (see Section 3.3 and Figure 3). We are currently unaware of any other study that has used Facebook likes to link two separate datasets in an analogical way, making our approach novel.

The notion that football may influence SWB is supported by a stream of research which has found that, apart from a list of standard factors influencing life satisfaction, such as age, health, income, relationship status, etc. (see e.g. Dolan et al. (2008) for an overview), other "unusual" and "seemingly unrelated" factors such as eating fruits and vegetables (Blanchflower et al., 2013), gas prices (Boyd-Swan \& Herbst, 2012), and even studying economics (Haucap \& Heimeshoff, 2014) have been found to affect life satisfaction. ${ }^{4}$

A closely related stream of literature has also looked for an analogous effect of

\footnotetext{
${ }^{4} \mathrm{~A}$ separate line of work finds the presence of short-term factors while examining the long-term validity of the life satisfaction question by studying test-retest correlations (Krueger \& Schkade, 2008) or order-of-question effects (Deaton \& Stone, 2013).
} 
weather on SWB measures and has so far delivered mixed evidence. ${ }^{5}$ To our knowledge, the first study to analyze this effect was Schwarz \& Clore (1983), which found that in an experimental setting, respondents tend to report higher life satisfaction on sunny days, as long as weather is not mentioned in the interview. However, using a large-scale cross sectional survey, ${ }^{6}$ Lucas \& Lawless (2013) find that although such effects exist, they are very weak. Schmiedeberg \& Schröder (2014) explored the phenomenon on a large panel dataset and found no evidence of the effect. Our study complements this stream of research in the sense that fans who care about the football team in question arguably care more about the team's results than an average person cares about the weather.

In order to better understand the relationship between sports and SWB, it is important to point out that our research interest lies in observing whether only unexpected outcomes matter. ${ }^{7}$ According to economic theory, rational agents are expected to form expectations according to information available ex ante (Card \& Dahl, 2011). In this particular setting, this means that fans' emotions are arguably likely to react differently when a result carries the element of surprise (relative to the benchmark formed by this expectation) than when it does not. Therefore, the methodology of this paper has been designed to allow for different effects of unexpected results. To check for whether reactions to unexpected outcomes differ from results which are not surprising, which we denote as general outcomes, ${ }^{8}$ the

\footnotetext{
${ }^{5}$ The two effects are similar in the sense that weather also may effect the mood of the consumer, but its regular day-to-day changes should arguably not impact her general life satisfaction.

${ }^{6}$ In fact, their study used the data from the same source this study utilizes.

${ }^{7}$ We define unexpected results based on the pre-game betting market valid in Las Vegas at kickoff time. See Section 3.1 for more information.

${ }^{8}$ Note that it is not possible to define such outcomes as expected, because unexpected results are defined as having been a result that carries a sufficient level of surprise.
} 
analysis below was constructed so as to allow us to distinguish between general and unexpected outcomes. Thus, in a sense, results of our analysis may be viewed as empirical validation of the reference-point utility of Koszegi \& Rabin (2006).

We find that unexpected wins have systematic effects on the reported life satisfaction of US residents. Specifically, following an unexpected win, the probability of a respondent reporting the highest life satisfaction category grows by approximately 4.5 percentage points. Further, back-of-the-envelope calculation suggests that the true value of the effect may be approximately 10 percentage points. Nevertheless, although the effect is sizable ex-post for several days following an unexpected win, its overall magnitude is negligible. Thus, it does not endanger comparisons of life satisfaction levels across regions and/or time.

The analysis also finds that there are no effects of unexpected losses, a result that is very surprising from two perspectives. First, in terms of knowledge of sports and SWB, Card \& Dahl (2011) find increases in domestic violence after unexpected football losses, but no decrease after an unexpected win, whereas our study finds exactly the opposite. Second, in terms of psychological research concerning changes in well-being, our results may be seen as complementary evidence to the experimental study of Yechiam et al. (2014), who find that in cases of one-shot interactions, people tend to report higher valuations of gains compared to losses. ${ }^{9}$

The remainder of this paper is structured as follows. Section 2 contains a brief literature review. Section 3 presents the data used in the estimation. Section 4 explains the methodology used in the analysis. Section 5 shows empirical results

\footnotetext{
${ }^{9}$ Yechiam et al. (2014) also present evidence that reporting feelings about wins and losses is not necessarily associated with behavioral biases. This can explain why our results seemingly go against the loss aversion theory.
} 
and discusses their importance. Section 6 discusses the robustness of our results to alternative specifications. Section 7 concludes.

\section{Literature Review}

Most of the previous literature on the effects of sports concentrated on stadiums and arenas and is not reviewed here. The conclusion of this literature is that stadiums where sports are played do not carry immediate economic benefits to the areas where they are built. For a thorough review of these studies, see Coates \& Humphreys (2008).

A stream of literature, e.g. Ahlfeldt \& Maennig (2010), Ahlfeldt \& Kavetsos (2011), have found that property prices in the surroundings of stadiums rise following its construction, suggesting a presence of beneficial intangible effects of sport arenas. On the contrary, Humphreys \& Nowak (2015) show that property values in the vicinity of Seattle's arena rose after the Seattle Supersonics moved to Oklahoma, indicating that the team had a detrimental effect on the local community. Although this study focuses on a different topic, these results may serve as an indicator of asset prices incorporating intangible benefits created by presence of sports teams.

\subsection{Psychological Effects of Sports}

A branch of literature explores situations where sport enters the psychological domain of agents, which in turn translates into their actions having "unrelated" impact.

Card \& Dahl (2011) find that the reported number of domestic assaults rises significantly in the three hours after a professional football game which the local team unexpectedly lost. Rees \& Schnepel (2009) obtain similar results in a sample 
of Division I college football games and extend its validity to a range of other criminal behavior in the town where the game is played.

Several studies have also found effects following wins of the local team. Agarwal et al. (2013) find evidence of a mortgage loan approval rates increasing by more than four percentage points following a big sports event leading to positive sentiment in affected counties. Fernquist (2000) finds that local teams making the playoffs lead to a lower suicide rate in the local population. Chen (2016) observes that immigration judges on average grant an additional $1.5 \%$ of asylum petitions on Mondays after the city's professional football team won compared to a loss. Healy et al. (2010) show that the probability of incumbents' reelection in the county of a college football team is approximately $1.5 \%$ higher if the particular team wins a game in the 10 days prior to the election.

A distinct stream of literature has focused on effects of sport teams on stock markets. Edmans et al. (2007) find that individual sentiment following a national team's loss in various sports leads to an abnormal negative return on the affected country's stock exchange. Drake et al. (2016) find that investors' distraction during the NCAA basketball tournament (known as the March Madness) creates stock disruptions that are present in the market for the period of 30 to 60 days.

\subsection{Sports and Subjective Well-Being}

To our knowledge, only few studies have examined the relationship between sports events and life satisfaction. Most of the existing research linking the two has concentrated on the effects of practicing sports on SWB and is not surveyed here. ${ }^{10}$

\footnotetext{
${ }^{10}$ See Section 2 of Kavetsos \& Szymanski (2010) for an overview.
} 
The earliest study to observe effects of sports events on life satisfaction is Schwarz et al. (1987) who found that German males reported a higher general life satisfaction after a 1982 World Cup soccer game that ended with a German win. Although their sample size is very limited, with only 55 observations, the authors conclude that this is an example of momentary happiness transcending into the long-term evaluation, implying the existence of the phenomenon this study aims to identify.

Kavetsos \& Szymanski (2010) examine data from 12 European countries to observe whether hosting an important tournament or having an unexpectedly successful soccer national team in a significant tournament, such as the Olympic games or the FIFA World Cup, have overall effects on life satisfaction reported by the country's citizens. Although their study finds limited evidence that the success of the national team has positive implications for inhabitants' life satisfaction, they do find a significant positive effect of hosting a large soccer tournament.

In a recent paper, Doerrenberg \& Siegloch (2014) examine whether being interviewed before or after an international soccer tournament has implications on several dependent variables, using a panel of unemployed individuals in Germany. Although the evidence is mixed for the case of life satisfaction, the study finds a significant decrease in general worries about the economic situation as well as a significant increase in the perceived intention to find work again.

Although the studies described above analyze effects of sports events on life satisfaction, there is a distinction between their and our approach. Namely, the previous work concentrates on short-timed, large scale tournaments, while this study examines the relationship on data from regular, week-to-week games. This elimi- 
nates the possibility of a spurious one-time effect that may have taken place around tournaments examined in previous studies. Moreover, the sample size associated with a large scale dataset allows us to examine potential heterogeneity of the effect in various decompositions, such as those based on differences in demographic characteristics or the extent of how surprising the result was (see Section 5.2 for more details). To our knowledge, this study is the first to examine the phenomenon in such settings.

\section{Data}

This section first introduces the two sources of data, football results and the BRFSS survey including dependent and control variables. Section 3.3 follows with a description of the novel method linking these two datasets.

\subsection{Football Results}

The data on football games were purchased from The Logical Approach ${ }^{11}$ and contain betting information available at the Las Vegas market at the kickoff time of each FBS ${ }^{12}$ college football game. As the second data set includes surveys conducted from 2005 to 2010, the sample consists of games played between 29th December 2004 and 28th December 2010.

The information about the expected result of a game is included in the spread, quoted as the expected number of points to equalize the two opponents valid on the Las Vegas betting market at kickoff time. For example, a spread of -10 means that the team was expected to win the game by 10 points (consequently, the opponent

\footnotetext{
${ }^{11}$ http: //www . thelogicalapproach.com/

${ }^{12} \mathrm{FBS}$ is the highest level of college football played in the United States.
} 


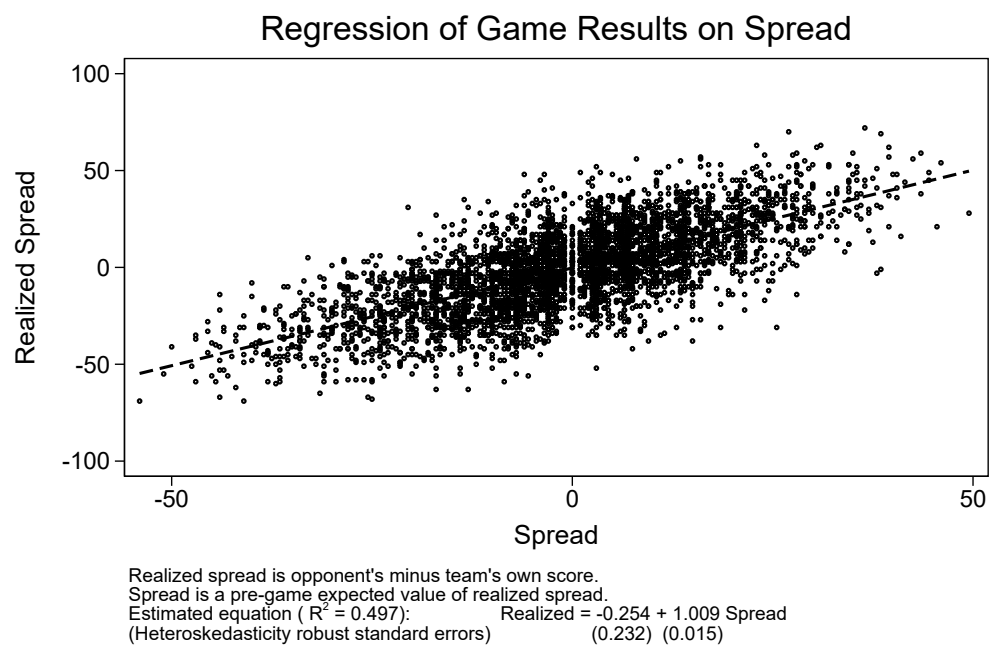

Figure 1: Predicted vs. Realized Spreads

would have the spread quoted as +10 and be expected to lose the game by 10 points).

Previous research (e.g. Sauer (1998), Fair \& Oster (2007) and Song et al. (2007)) has shown that spreads contain the most relevant information that is available ex ante about the outcome of a football game. Our data is consistent with their conclusions, as the regression estimate of the realized value of the spread on its value yields a coefficient of 1.01 with a standard deviation of 0.015 , a level that is statistically not significant from the market-efficient value of 1 (see Figure 1). Therefore, we can use the spread to control for the ex ante probability of a particular team winning the game.

A result is defined as unexpected if it goes against the spread of 9 points or more in an absolute value. This specific value was selected as it breaks the set of games to approximately one quarter below and above the threshold (see Table 3.1), ensuring that the surprise effect is sufficiently strong, while still keeping enough games to allow for a sizable number of unexpected results. In this sense, the selection is very similar to Card \& Dahl's (2011) study who use 4 points on NFL data associated 
with a lower volatility of spreads. ${ }^{13}$ In fact, the 75 th percentile in their data is equal to 4 points, making our selection comparable after accounting for the difference in the volatility of spreads between the two competitions. Moreover, 9 points is especially useful from the view of football rules, as it is the lowest point difference in a two-possession game. ${ }^{14}$

Table 3.1: Frequencies of Games by Cutoff Spread

\begin{tabular}{lrrr}
\hline Spread & No. & Col \% & Cum \% \\
\hline Lower or equal -9 points & 2,182 & 25.4 & 25.4 \\
Between -9 and 9 points & 4,296 & 50.1 & 75.6 \\
Higher or equal 9 points & 2,096 & 24.4 & 100.0 \\
Total & 8,574 & 100.0 & \\
\hline
\end{tabular}

Source: Author's computation based on games from 2005 until 2010 .

Figure 2 shows the probability a team will win the game based on the spread. The expected probability of winning is less than or equal to $36.4 \%$ once the spread is higher than or equal to 9 . The probability of an unexpected loss is less than or equal to $39.2 \%$ for unexpected losses with a spread lower than or equal to $-9 .{ }^{15}$

\subsection{Behavioral Risk Factor Surveillance System}

The second data source used is the Behavioral Risk Factor Surveillance System (BRFSS), collected daily by the Centers for Disease Control and Prevention (CDC) on a wide-ranging sample of American citizens, resulting in a yearly sample size of

\footnotetext{
${ }^{13}$ NFL (National Football League) is the major professional football league in the United States.

${ }^{14}$ In football, when a team scores a touchdown, it receives six points. It then attempts one more play (called "point after try" ) for which it receives zero, one, or two points. Therefore, once the point difference reaches 9 points, the trailing team has to score at least twice to win the game.

${ }^{15}$ Note that these values present the average probability of a surprise result and do not account for differences in team characteristics. Generally, the probability of an unexpected win will be very low for successful teams that almost never lose, as they will extremely rarely be expected to lose the game by a sufficient margin. Heterogeneity of the effect based on team quality is examined in Section 5.2.3.
} 


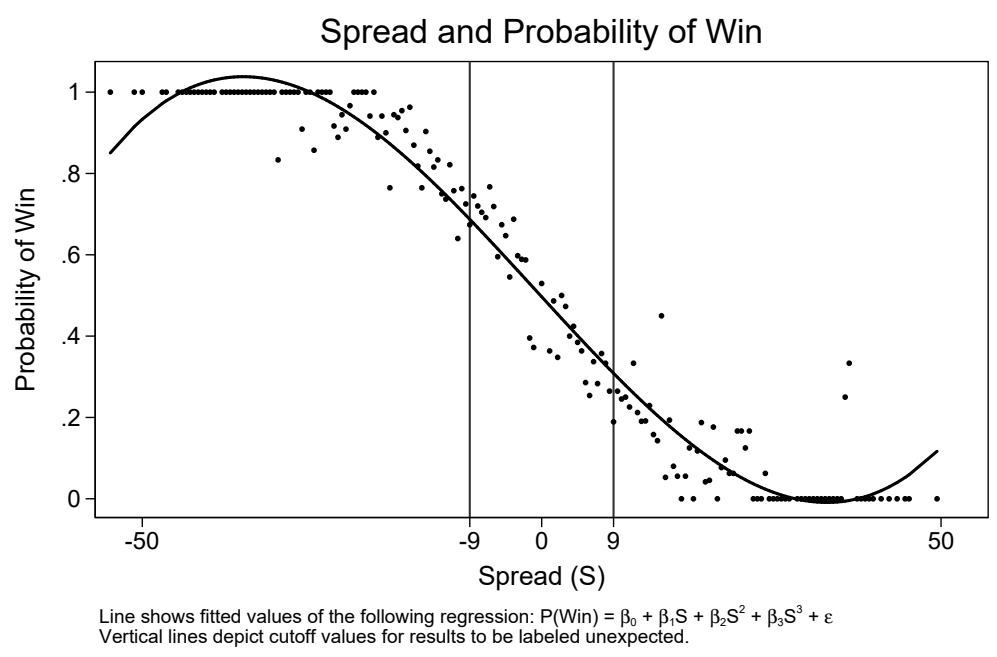

Figure 2: Spread and Probability of Win

about 400,000 observations.

The BRFSS is a system of telephone surveys that collects data about U.S. residents regarding their health-related risk behaviors, chronic health conditions, and use of preventive health services. Although the cross-sectional nature of the data inevitably leads to an issue of unobserved heterogeneity, the BRFSS has three main advantages which make it very convenient for our particular setting. First, from 2005 to $2010,{ }^{16}$ the survey contained a life satisfaction question where respondents self-evaluate themselves on a scale from 1 to 4 by answering the question "In general, how satisfied are you with your life?", with options labeled (from 1 to 4) "very satisfied", "satisfied", "dissatisfied" and "very dissatisfied". ${ }^{17}$

Second, the data set contains county codes, allowing a much closer geographic link than in the case of data sets which only contain state level identification. As there are multiple FBS football teams in most states, we need such information to

\footnotetext{
${ }^{16}$ Since 2011, the question has been moved into the optional part of the questionnaire and is asked in only a small number of states.

${ }^{17}$ Throughout this study, the scale was reverse-coded in order for the higher value to represent greater satisfaction with life.
} 
match the particular observation to the appropriate team.

Third, the availability of exact survey date allows us to identify whether the local football team had won or lost the game prior to the survey.

\subsection{Linking Games to Observations}

The crucial question after obtaining the data on survey responses and football games is how to link a specific game to a particular observation (it is straightforward that it may not be sufficient to simply take the closest geographical team to the area where the respondent lives). As mentioned in the introduction, our method uses the data from Facebook likes. Specifically, it looks at which team has the biggest share of likes in a given geographical location.

The data on Facebook likes in each ZIP code area were downloaded from the New York Times website, which published a study and an associated interactive map about the distribution of college football fans throughout the USA. ${ }^{18}$

Information on likes for these ZIP codes was then matched to data in specific counties based on the division in the 2010 census. In order to link the ZIP codes to our county-identified observations, we used the 2010 ZIP Code Tabulation Area (ZCTA) Relationship File provided by the US census. ${ }^{19}$ Percentages from these ZIP codes were then weighted by their respective populations in order to obtain the relative percentage of likes for each applicable county.

In total, the six years of BRFSS surveyed 2,440,925 respondents. After restricting the sample for the period of one week prior to the first and one week after the last game of each season and matching the data to football results, we obtained

\footnotetext{
${ }^{18}$ http://www.nytimes.com/interactive/2014/10/03/upshot/ncaa-football-map.html

${ }^{19}$ https://www.census.gov/geo/maps-data/data/zcta_rel_layout.html
} 
the dataset of 576,128 observations. However, a substantial issue with this simple matching is that it links all observations in a given area to one team, which may not be actually supported by all football fans living in the area, introducing a measurement error into the model. In order to mitigate this issue, the sample was further restricted to only take into account areas where a specific team can be considered dominant. Therefore, only areas where the major team claims more than half of the total number of fans are used. Thus, the baseline sample includes 194,569 observations.

Although this reduces the sample size to about a third and the number of games used to approximately half, ${ }^{20}$ this step should arguably help to reveal the effect in question. Moreover, as discussed in Section 6.1.1, the actual choice of cutoff percentage does not substantially alter the results.

The specific frequencies of the life satisfaction categories in the baseline sample are reported in Table 3.2. Note that the vast majority of responses falls into the

Table 3.2: Life Satisfaction Frequencies

\begin{tabular}{lrrr}
\hline Life Satisfaction & No. & Col \% & Cum \% \\
\hline Very Dissatisfied & 2,263 & 1.2 & 1.2 \\
Dissatisfied & 9,139 & 4.7 & 5.9 \\
Satisfied & 95,671 & 49.2 & 55.0 \\
Very Satisfied & 87,496 & 45.0 & 100.0 \\
Total & 194,569 & 100.0 & \\
\hline
\end{tabular}

Source: BRFSS for period from 2005 to 2010.

Area coverage shown in Figure 3.

top two out of the four categories, which complicates the analysis in the sense that smoother adjustments along the scale are not possible. However, as larger changes

\footnotetext{
${ }^{20}$ The restricted sample is matched with results of 4,246 games.
} 
in valuation of life satisfaction are needed to prospect into its measurement, this could be viewed as a sort of an attenuation bias in the sense that some information is lost by rounding of the actual feeling. ${ }^{21}$

Areas included in the analysis are depicted in Figure 3. Examining the composition of teams in the data, ${ }^{22}$ the University of Oregon and Louisville are the only two teams that have majority support from outside their state borders. Moreover, states that are generally strong in football such as Texas, California, and Alabama contain counties with differing team fan bases within the state.

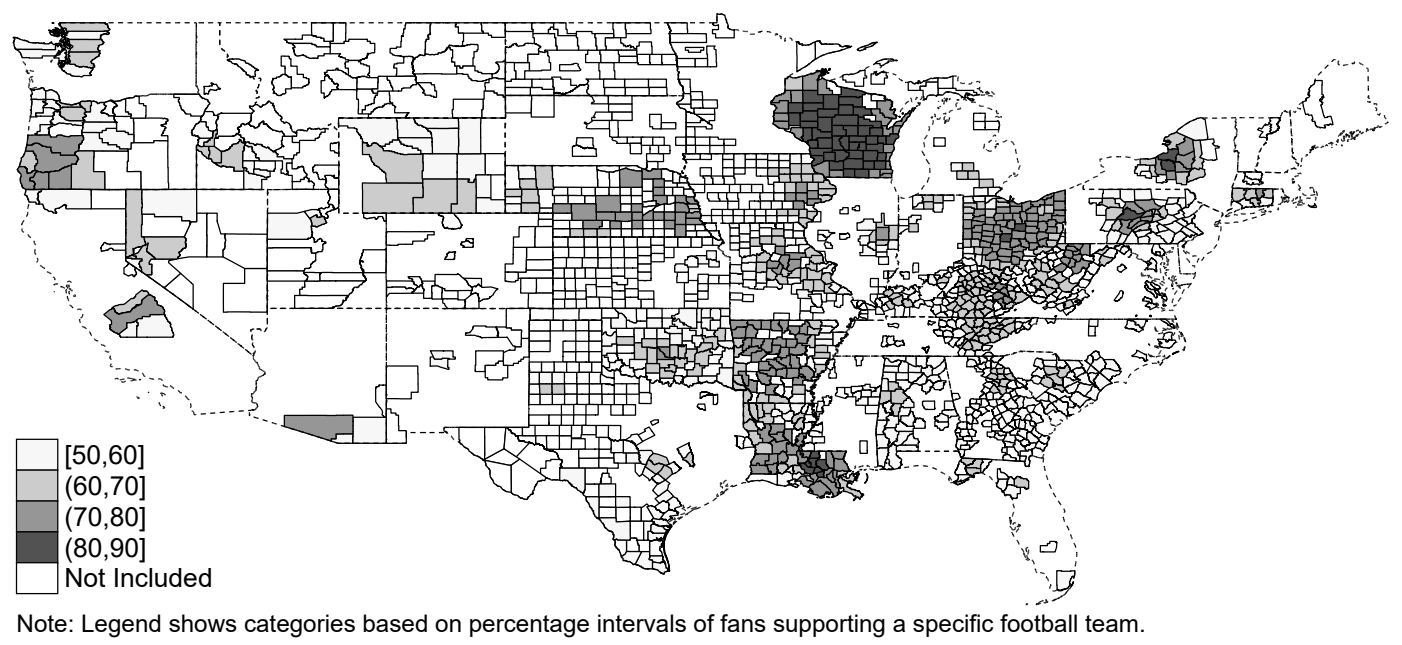

Figure 3: Areas Included in the Analysis

\section{Methodology}

Due to the fact that our dependent variable, life satisfaction, is measured on an ordinal scale, a limited dependent variable model was used. Specifically, an ordered logit model was selected, as its functional form allows for fixed effects.

\footnotetext{
${ }^{21}$ Statistically speaking, while it increases the chance of a type II error, it decreases the chance of a type I error.

${ }^{22}$ For a complete list of teams and states, see Table B.1 in the Appendix.
} 
The functional form of the model follows the equation

$$
\begin{aligned}
& y_{i j t}^{*}=\theta_{j}+\xi_{t}+X_{i j t} \beta+g\left(S_{j t}, w_{j t}, d_{i j t}\right)+\varepsilon_{i j t} \\
& y_{i j t}=k \quad \text { if } \kappa_{k-1}<y_{i j t}^{*} \leq \kappa_{k}
\end{aligned}
$$

where $\theta_{j}$ and $\xi_{t}$ are regional and time fixed effects and $X_{i j t}$ is a vector of control variables described below. The function $g\left(S_{j t}, w_{j t}, d_{i j t}\right)$ was designed to capture the effects of football results and their (un)expectedness. It takes the form

$$
\begin{aligned}
g\left(S_{j t}, w_{j t}, d_{i j t}\right)= & \lambda_{1} \cdot 1\left[S_{j t} \geq 9\right] \cdot 1\left[w_{j t}=1\right] \cdot 1\left[0<d_{i j t} \leq 3\right]+ \\
& \lambda_{2} \cdot 1\left[S_{j t} \leq-9\right] \cdot 1\left[w_{j t}=0\right] \cdot 1\left[0<d_{i j t} \leq 3\right]+ \\
& \gamma_{1} \cdot 1\left[S_{j t} \geq 9\right] \cdot 1\left[w_{j t}=1\right]+ \\
& \gamma_{2} \cdot 1\left[S_{j t} \leq-9\right] \cdot\left[w_{j t}=0\right]+ \\
& \delta_{1} \cdot 1\left[w_{j t}=1\right]+ \\
& \delta_{2} \cdot 1\left[0<d_{i j t} \leq 3\right]+ \\
& \delta_{3} \cdot 1\left[w_{j t}=1\right] \cdot 1\left[0<d_{i j t} \leq 3\right]
\end{aligned}
$$

where $S_{j t}$ denotes the pre-game betting spread, $w_{j t}$ is a dummy variable equal to one if the specific team won the previous game and zero if it lost, and $d_{i j t}$ is the number of days between the previous game and date of the survey, indicating whether or not the game fell into the post-game window, defined as within the period of three days after the particular game was played.

The selection of the length of the post-game window lies mainly in the fact that the sample of observations in periods where teams play week-by-week games is broken down to approximately half of the period between the two games. We would suspect that the effect would be stronger within a shorter period, however, 
we decided to choose a relatively longer one in order to ensure a sufficient number of identifying observations (note that as we do not know the exact timing of the survey, we need to exclude days when a game took place). The robustness of this selection is presented in Section 6.1.3.

Our particular research interest lies in parameters $\lambda_{1}$ and $\lambda_{2}$. Specifically, in the case that only unexpected football results during the post-game window have effects on life satisfaction of the population, $\lambda_{1}$ would be positive, and $\lambda_{2}$ would be negative, while the other coefficients of $g\left(S_{j t}, w_{j t}, d_{i j t}\right)$ would be zero. In case unexpected results have effects regardless of whether the survey takes place in the post-game window, coefficient $\gamma_{1}$ would be positive and coefficient $\gamma_{2}$ negative. If there is an effect of a win in the post-game window in general, but there is no additional effect of an unexpected win, coefficient $\delta_{3}$ would be positive along with $\lambda_{1}$ and $\gamma_{1}$ being zero.

Coefficient $\delta_{1}$ measures the general effect of a win, coefficient $\delta_{2}$ controls for a potential effect of the post-game window, and coefficient $\delta_{3}$ measures a general effect of a win in the post-game window.

Based on the results of previous studies (see e.g. Dolan et al. (2008)) and on the data available, the control variables contained in vector $X_{i j t}$ can be broken down into several categories. First, we include the data on an individual's characteristics age and age squared, gender, and whether there are children living in the household. Second, we include several sets of dummies reflecting the respondents' marital status, employment status, education, and income. Third, health proxies are included variables on participation in physical exercise, being limited in activity and variables 
regarding smoking are used. See Table A.1 in the Appendix for an overview of survey questions associated with these variables.

\section{Results}

\subsection{Baseline Analysis}

Results of the analysis are presented in Tables 5.1 and 5.2, with the former showing several regressions, including the baseline in column 4, and the latter presenting probability derivatives from the baseline regression. Standard errors in all regressions were adjusted for clustering on a county level, and the baseline estimation includes the set of football variables, the vector of controls, weekly fixed effects and team-state fixed effects.

Note that, with the exception of Tables 5.2, 6.2, and A.4, all regression-related tables in this study present regression coefficients rather than marginal effects. The reason for this is that with the four outcomes of the dependent variable, the ordered logit model implies four different marginal effects, which would make the outputs of our regressions much less tractable.

We can see that the coefficient on an unexpected win in the post-game window is positive and statistically significant throughout all specifications. However, coefficients for unexpected loss remain insignificant in all regressions, suggesting the effects of unexpected win and loss are not symmetrical. ${ }^{23}$

The fact that an effect is found for unexpected wins but not losses seems surprising in terms of the previous knowledge. As noted earlier, Card \& Dahl (2011) found an increase in family violence following an unexpected loss, but no decrease after

\footnotetext{
${ }^{23}$ In this sense, these results present empirical evidence of the existence of reference dependent preferences.
} 
Table 5.1: Baseline Regression: Ordered Logit Coefficients Dependent Variable: Life Satisfaction

\begin{tabular}{|c|c|c|c|c|}
\hline & (1) & $(2)$ & $(3)$ & $(4)$ \\
\hline$\lambda_{1}:$ Unexp. Win $^{1} \times$ Window $^{2}$ & $\begin{array}{l}.179^{* * *} \\
(0.07)\end{array}$ & $\begin{array}{l}.212^{* * *} \\
(0.07)\end{array}$ & $\begin{array}{l}.204^{* * *} \\
(0.07)\end{array}$ & $\begin{array}{l}.207^{* * *} \\
(0.07)\end{array}$ \\
\hline$\lambda_{2}:$ Unexp. Loss $^{1} \times$ Window $^{2}$ & $\begin{array}{c}.032 \\
(0.06)\end{array}$ & $\begin{array}{c}.019 \\
(0.06)\end{array}$ & $\begin{array}{c}4.4 \mathrm{e}-03 \\
(0.06)\end{array}$ & $\begin{array}{c}7.0 \mathrm{e}-03 \\
(0.06)\end{array}$ \\
\hline$\gamma_{1}:$ Unexpected $\mathrm{Win}^{1}$ & $\begin{array}{l}-.023 \\
(0.04)\end{array}$ & $\begin{array}{c}-.08^{* *} \\
(0.04)\end{array}$ & $\begin{array}{l}-.067 \\
(0.04)\end{array}$ & $\begin{array}{l}-.053 \\
(0.04)\end{array}$ \\
\hline$\gamma_{2}:$ Unexpected Loss ${ }^{1}$ & $\begin{array}{c}.023 \\
(0.03)\end{array}$ & $\begin{array}{c}.021 \\
(0.04)\end{array}$ & $\begin{array}{c}.032 \\
(0.04)\end{array}$ & $\begin{array}{c}.021 \\
(0.04)\end{array}$ \\
\hline$\delta_{1}:$ Win & $\begin{array}{l}-.013 \\
(0.01)\end{array}$ & $\begin{array}{c}-6.5 \mathrm{e}-03 \\
(0.02)\end{array}$ & $\begin{array}{c}-6.6 \mathrm{e}-03 \\
(0.02)\end{array}$ & $\begin{array}{c}-8.0 \mathrm{e}-03 \\
(0.01)\end{array}$ \\
\hline$\delta_{2}:$ Post-Game Window $^{2}$ & $\begin{array}{c}.02 \\
(0.02)\end{array}$ & $\begin{array}{l}-.012 \\
(0.02)\end{array}$ & $\begin{array}{c}-5.5 \mathrm{e}-03 \\
(0.02)\end{array}$ & $\begin{array}{c}7.5 \mathrm{e}-03 \\
(0.02)\end{array}$ \\
\hline$\delta_{3}:$ Win $\times$ Post-Game Window ${ }^{2}$ & $\begin{array}{l}-.025 \\
(0.02)\end{array}$ & $\begin{array}{l}-.012 \\
(0.02)\end{array}$ & $\begin{array}{l}-.013 \\
(0.02)\end{array}$ & $\begin{array}{l}-.028 \\
(0.02)\end{array}$ \\
\hline Controls $^{3}$ & No & Yes & Yes & Yes \\
\hline Weekly fixed effects & No & No & Yes & Yes \\
\hline State-team fixed effects & No & No & No & Yes \\
\hline Observations & 197104 & 194569 & 194569 & 194569 \\
\hline
\end{tabular}

Standard errors adjusted for clusters on the county level in parentheses.

Significance levels: ${ }^{*} p<0.10,{ }^{* *} p<0.05,{ }^{* * *} p<0.01$

${ }^{1} \mathrm{~A}$ win by a team expected to lose by at least 9 points given pre-game betting spread.

${ }^{2}$ Post-game window is a period of three days after the last game was played.

${ }^{3}$ Controls include individual's personal, economic and health variables. See Appendix A for details.

Source: Estimation of the ordered logit model. 
an unexpected win. In a sense, our results may be seen as complementary evidence to the experimental study of Yechiam et al. (2014), who find that people tend to report valuations of gains higher than in case of losses of the same magnitude.

The marginal effects from the baseline estimation are shown in Table 5.2. Following an unexpected win, the probability that a respondent reports being very satisfied rises by approximately $4.5 \%$ regardless of which combinations of football covariates one considers. This suggests that, on average, one person of 22 would overestimate their actual life satisfaction following an unexpected win.

Table 5.2: Baseline Regression: Marginal Effects of Unexpected Wins

\begin{tabular}{lcccc} 
Life Satisfaction & \multicolumn{2}{c}{ Probability } & Window $^{2}$ & Outside $^{3}$ \\
& Sample & Model & ME ( Low, High $)$ & ME ( Low, High $)$ \\
\hline Very Dissatisfied & 0.012 & 0.012 & $-0.002(-0.004,-0.001)$ & $-0.002(-0.004,-0.001)$ \\
Dissatisfied & 0.047 & 0.048 & $-0.009(-0.015,-0.003)$ & $-0.009(-0.014,-0.003)$ \\
Satisfied & 0.492 & 0.493 & $-0.034(-0.056,-0.011)$ & $-0.034(-0.057,-0.011)$ \\
Very Satisfied & 0.450 & 0.447 & $0.045(0.014,0.075)$ & $0.045(0.015,0.075)$ \\
\hline
\end{tabular}

Table shows marginal effects of an unexpected win in the post-game window $\left(\lambda_{1}\right)$.

All coefficients are statistically significant at $99 \%$.

95\% confidence intervals reported in parenthesis.

${ }^{1}$ Probability of the survey answer to the life satisfaction question in the estimation sample and predicted probability of the particular answer from the estimated model.

${ }^{2}$ Marginal effect of an unexpected win in the post-game window compared to a general win in the post-game window.

${ }^{3}$ Marginal effect of an unexpected win in the post-game window compared to a general win outside of the post-game window.

Source: Estimation of the ordered logit model.

Moreover, even though we only use data from areas where a majority of fans supports one team, there is no way to identify which observation comes from a fan and which does not. Assuming the distribution of fans is homogeneous in the United States, market research estimated that $43 \%$ of citizens were college football fans. ${ }^{24}$ Using a simple back of the envelope calculation, this would suggest that the probability of answering with the highest category would increase by slightly

\footnotetext{
${ }^{24}$ http://sportsaffiliates.learfieldsports.com/files/2012/11/College-vs. -Pro.pdf
} 
above $10 \%$ following an unexpected win. Note, moreover, that even this back-ofthe-envelope calculation may likely be biased downward, as the market estimate in question defined a college football fan as a person who had watched, attended or listened to a game in the 12 months prior to the survey being taken.

Note that even though the effect is statistically significant and may be seen as sizable, it may also be viewed as negligible from the point of view of the overall aggregated measure. Specifically, the data show that the long term mean is distorted by a fraction of 0.0006 of a standard deviation in the overall data set. This means that the effect does not present an issue for life satisfaction comparisons through regions and/or time.

Coefficients on most of the control variables are strongly statistically significant with a sign that is in line with the previous literature. ${ }^{25}$ However, as this study concentrates on effects of football on life satisfaction, coefficients of these control variables are not reported here. Full regression results are presented in Appendix A.

\section{$5.2 \quad$ Effect Heterogeneity}

While the previous section suggests that if there is an effect of football on reported life satisfaction, it will probably be the effect of unexpected win. However, the section does not address the possibility of this effect being heterogeneous. In this section, we utilize the advantage of a relatively large sample and try to identify groups for which the effect differs based on demographic, geopolitical, and team

\footnotetext{
${ }^{25}$ For example, life satisfaction follows a U-shaped pattern throughout individuals' age (Blanchflower \& Oswald, 2008), household income generally has a positive effect (Huang \& Humphreys, 2012), and children seem to cause lower life satisfaction (Deaton \& Stone, 2014).
} 
characteristics. Results of all regressions discussed in this section are reported in Table 5.3.

\subsubsection{Demographic Characteristics}

Results of regressions on subsamples based on gender and education are reported in the first four columns of 5.3. The education-based distinction is important due to the fact that the study analyzes results of college teams - while non-graduates may still identify with a college team, the effects should arguably be stronger for alumni.

Interestingly, the effect seems to be driven by female rather than male respondents, an effect we find puzzling as men are generally viewed as being associated with stronger fan connections than women. One possible explanation could be that the short to long-term transmission mechanism from happiness to life satisfaction is stronger for women than for men. However, note that the two coefficients are not statistically different from each other.

As expected, the point estimate of the effect for college graduates is stronger than for non-graduates (specifically, the probability derivative with respect to the coefficient on an unexpected win is calculated as $3.6 \%$ in the case of non-graduates and $6 \%$ for graduates). This is likely because being a college alumni creates a psychological attachment to the school, hence the emotions and feelings related to the particular football team may likely be stronger. However, similarly to the case above, the two coefficients are not statistically different from each other.

\subsubsection{County Characteristics}

The second distinction of the effect explores possible heterogeneity based on a geopolitical county position. Specifically, we ran separate regressions where the sample 
Table 5.3: Heterogeneity of Effect Regressions: Ordered Logit Coefficients

Dependent Variable: Life Satisfaction

\begin{tabular}{|c|c|c|c|c|c|c|c|c|c|c|c|c|c|c|c|}
\hline & \multicolumn{4}{|c|}{ Demographic Groups (5.2.1) } & \multicolumn{4}{|c|}{ County Specifics (5.2.2) } & \multicolumn{6}{|c|}{ Football Characteristics (5.2.3) } & \multirow{3}{*}{$\begin{array}{c}\text { Base } \\
\text { All }\end{array}$} \\
\hline & \multicolumn{2}{|c|}{ Gender } & \multicolumn{2}{|c|}{ College Grad $^{1}$} & \multicolumn{2}{|c|}{$\mathrm{MSA}^{2}$} & \multicolumn{2}{|c|}{ Politics $^{3}$} & \multicolumn{2}{|c|}{ Team Quality $^{4}$} & \multicolumn{2}{|c|}{ Location } & \multicolumn{2}{|c|}{ Important Game ${ }^{5}$} & \\
\hline & M & $\mathrm{F}$ & Yes & No & Yes & No & Dem & Rep & Good & Bad & Home & Road & Yes & No & \\
\hline \multirow{2}{*}{$\lambda_{1}$} & $.172^{*}$ & $.227^{* *}$ & $.271^{* *}$ & $.172^{* *}$ & $.156^{*}$ & $.294^{* *}$ & .147 & $.328 * *$ & $.283^{* *}$ & $.175^{*}$ & $.45^{* * *}$ & .102 & $.345^{* *}$ & $.213^{* *}$ & $.207^{* * *}$ \\
\hline & $(0.10)$ & $(0.10)$ & $(0.13)$ & $(0.08)$ & $(0.08)$ & $(0.13)$ & $(0.10)$ & $(0.13)$ & $(0.11)$ & $(0.11)$ & $(0.15)$ & $(0.08)$ & $(0.16)$ & $(0.09)$ & $(0.07)$ \\
\hline \multirow[t]{2}{*}{$\lambda_{2}$} & .142 & -.065 & .099 & -.03 & $3.6 \mathrm{e}-03$ & .011 & .121 & -.087 & $-9.8 \mathrm{e}-03$ & .011 & -.032 & .172 & .051 & $-2.6 \mathrm{e}-03$ & 7.0e-03 \\
\hline & $(0.10)$ & $(0.07)$ & $(0.12)$ & $(0.07)$ & $(0.07)$ & $(0.12)$ & $(0.08)$ & $(0.10)$ & $(0.07)$ & $(0.11)$ & $(0.08)$ & $(0.11)$ & $(0.12)$ & $(0.07)$ & $(0.06)$ \\
\hline \multirow[t]{2}{*}{$\gamma_{1}$} & -.033 & -.062 & -.052 & -.058 & -.069 & -.021 & -.046 & -.062 & -.021 & $-.128^{*}$ & -.147 & -.011 & .057 & $-.092^{*}$ & -.053 \\
\hline & $(0.07)$ & $(0.05)$ & $(0.08)$ & $(0.05)$ & $(0.05)$ & $(0.08)$ & $(0.08)$ & $(0.07)$ & $(0.06)$ & $(0.07)$ & $(0.11)$ & $(0.05)$ & $(0.08)$ & $(0.06)$ & $(0.04)$ \\
\hline \multirow[t]{2}{*}{$\gamma_{2}$} & -.049 & .062 & $3.4 \mathrm{e}-04$ & .027 & .029 & .015 & .028 & .026 & .013 & .034 & .034 & -.01 & .055 & $9.2 \mathrm{e}-03$ & .021 \\
\hline & $(0.06)$ & $(0.05)$ & $(0.08)$ & $(0.05)$ & $(0.04)$ & $(0.07)$ & $(0.05)$ & $(0.06)$ & $(0.04)$ & $(0.08)$ & $(0.05)$ & $(0.07)$ & $(0.08)$ & $(0.04)$ & $(0.04)$ \\
\hline$\delta_{1}$ & $\begin{array}{c}-9.5 \mathrm{e}-03 \\
(0.02)\end{array}$ & $\begin{array}{c}-6.6 \mathrm{e}-03 \\
(0.02)\end{array}$ & $\begin{array}{c}-9.8 \mathrm{e}-03 \\
(0.03)\end{array}$ & $\begin{array}{c}-6.8 \mathrm{e}-03 \\
(0.02)\end{array}$ & $\begin{array}{c}-8.5 \mathrm{e}-03 \\
(0.02)\end{array}$ & $\begin{array}{c}-6.1 \mathrm{e}-03 \\
(0.02)\end{array}$ & $\begin{array}{l}5.0 \mathrm{e}-03 \\
(0.03)\end{array}$ & 7.5e-03 & $-9.7 \mathrm{e}-03$ & $6.7 \mathrm{e}-03$ & .013 & $-.033^{*}$ & -.025 & $-9.2 \mathrm{e}-04$ & $-8.0 \mathrm{e}-03$ \\
\hline \multirow[t]{2}{*}{$\delta_{2}$} & $\begin{array}{l}.023 \\
.023\end{array}$ & $-2.0 \mathrm{e}-03$ & $4.8 \mathrm{e}-04$ & $8.6 \mathrm{e}-03$ & .021 & $\begin{array}{l}(0.02) \\
-.027\end{array}$ & $7.2 \mathrm{e}-03$ & .022 & $\begin{array}{c}(0.02) \\
.012\end{array}$ & $\begin{array}{c}(0.00) \\
-5.7 \mathrm{e}-03\end{array}$ & $\begin{array}{l}(0.02) \\
-.021\end{array}$ & $\begin{array}{c}(0.02) \\
.025\end{array}$ & $\begin{array}{l}(0.03) \\
-.028\end{array}$ & $\begin{array}{c}(0.02) \\
.011\end{array}$ & $7.5 \mathrm{e}-03$ \\
\hline & $(0.03)$ & $(0.02)$ & $(0.03)$ & $(0.02)$ & $(0.02)$ & $(0.03)$ & $(0.02)$ & $(0.03)$ & $(0.02)$ & $(0.03)$ & $(0.03)$ & $(0.02)$ & $(0.04)$ & $\begin{array}{l}.011 \\
(0.02)\end{array}$ & $(0.02)$ \\
\hline \multirow[t]{2}{*}{$\delta_{3}$} & -.046 & -.017 & $-.067^{*}$ & -.01 & $-.045^{*}$ & .013 & -.016 & -.047 & -.034 & $-6.3 \mathrm{e}-03$ & -.022 & -.014 & -.022 & -.024 & -.028 \\
\hline & $(0.03)$ & $(0.03)$ & $(0.04)$ & $(0.03)$ & $(0.03)$ & $(0.04)$ & $(0.04)$ & $(0.03)$ & $(0.03)$ & $(0.04)$ & $(0.04)$ & $(0.03)$ & $(0.05)$ & $(0.03)$ & $(0.02)$ \\
\hline $\mathrm{N}$ & 72764 & 121805 & 62060 & 132509 & 135591 & 58978 & 82480 & 87417 & 137479 & 57090 & 94726 & 99843 & 51193 & 143376 & 194569 \\
\hline
\end{tabular}

The table shows separate regressions of the baseline sample broken down into subgroups defined by the third line in the header. The second line of the header describes the type of breakdown, and the first line points to sections of text with a more detailed description.

Greek letters correspond to regression coefficients (see equation 3 in Section 4 for definition and other output tables for labels).

All columns include a full set of controls, weekly fixed effects, and state-team fixed effects. Standard errors adjusted for clusters on the county level in parentheses.

Significance levels: ${ }^{*} p<0.10,{ }^{* *} p<0.05,{ }^{* * *} p<0.01$

${ }^{1}$ Sample divided into respondents who have college education and those who do not.

${ }^{2}$ Coded as "Yes" if the county falls into a Metropolitan Statistical Area.

${ }^{3}$ Counties divided based on results of the 2008 presidential elections. Samples restricted based on having a minimum $5 \%$ margin in the final outcome.

${ }^{4}$ The first two columns sort teams by quality based on their performance in the current and previous season.

${ }^{5}$ An important game defined as either last week of the regular season or game with bowl-eligibility implications.

Source: Estimation of the ordered logit model. 
was broken down based on whether the county is in a metropolitan statistical area (MSA), and the political preference of the county's citizens in the 2008 presidential elections. ${ }^{26}$ Results of the analysis can be found in the middle section of Table 5.3.

The results indicate that the effect in question may be stronger in non-metropolitan areas. This is not surprising as it could be argued that college football is mainly followed in areas with lower population density. Even though the two coefficients are statistically not significantly different, these results may indicate why previous studies on the effects of sports did not concentrate on the relationship between football and life satisfaction, as they mostly used data from MSA areas only.

The second distinction shows the analysis broken down into counties that voted for Democratic and Republican candidates in the 2008 presidential election. ${ }^{27}$ Interestingly, these results suggest that the overall effect is driven mainly by counties with majority support for Republicans. Although there are several possible explanations for this effect, all of them are likely linked by the fact that the demographic characteristics of Republican voters substantially overlap with those of football fans. In fact, study by the National Media Research, Planning and Placement (NRMPP), analyzing data from 2008 and 2009, has shown that college football is the second most Republican-supported sport, in between PGA golf and Nascar racing. ${ }^{28}$ According to this study, college football is followed by mostly Republican fans, while

\footnotetext{
${ }^{26}$ Although the debate about the polarization of the American electorate is recently livelier than ever, research has shown that election decisions are based on a wider set of domains than purely economical (see introduction to Ansolabehere et al. (2006) for more information). Therefore, there is a chance that attitudes towards sports differ between voters of the two parties.

${ }^{27}$ To avoid any possible influence of counties that almost tied, we excluded counties where the winning candidate had a margin of less than $5 \%$. Therefore the sample sizes do not add up to the overall number of observations.

${ }^{28}$ Accessed through wayback machine at https://web.archive.org/web/20110304071230/ http://nmrpp.com/assets/NMRPPsportspolitics.pdf
} 
Democratic fans more often follow other sports such as NBA or tennis. In light of this result, it is not surprising that our findings are driven by counties with predominantly Republican support.

\subsubsection{Football Characteristics}

While the previous sections look at how the effect differs based on the demographic groups of respondents and a county's position in terms of geopolitical characteristics, the effect may also differ depending on what football game was played. This section explores possible heterogeneities in three football-related areas: the quality of the team in question, location of the game, and whether the game may be viewed as a relatively more important one. Results of these regressions are shown in the right section of Table 5.3.

The first two columns of the section examine a possibility that the effect could be different for teams of varying quality. In order to examine this possibility, we broke the teams down into good and bad depending on their success. This division was done according to the criterion of having more wins than losses in the second half of the current season. In order to avoid noise in a signal of quality of the team in the first half of the season, observations falling into the first six games of each season have been graded by the same logic based on the final record of the previous season.

The results seem to suggest that an unexpected win by an above-average team against a great team is more pronounced than an unexpected win by a below-average team against an above-average or top team. Nevertheless, although the coefficients 
have different point estimates, they are not statistically different. ${ }^{29}$

Columns labeled "Location" look at the effects following home and road games. The results suggest that the overall effect is driven mainly by home games, with the marginal effect being an increase in the probability of reporting the highest life satisfaction answer by $9.7 \%$, associated with more than one of each 11 respondents misreporting the life satisfaction level. Moreover, the coefficient on road games is not statistically significant. This may be explained by the difference between the two types of games - while fans usually watch road games on TV, many of them likely attend home games in person. Home games also matter more in smaller communities, as the surroundings of the stadium are impacted by the influx of fans, tailgate parties, and other activities associated with a home game. Therefore, home games arguably lead to stronger emotional cues, which may then be more likely to enter the transmission mechanism.

The effect may also be different based the relative importance of the game. We define the game as important if it satisfies one (or both) of the following conditions:

1. It is a rivalry game or a post-season game. In order to proxy for rivalry games, we use the last week of regular season, which is known as rivalry week.

2. The team had 6 wins or 6 losses before the game. Such games are important as college football teams do not have a traditional playoff system, but rather compete in a post-season one-shot games known as bowls. Although there are some exceptions, in order to be bowl-eligible, the team generally needs

\footnotetext{
${ }^{29}$ Note also that even though the division of teams into good and bad results in approximately half of teams in each group, the sample sizes of both regressions are different. This is caused by the requirement of majority of fans supporting one team in the given county. In other words, better quality teams tend to have higher fan support.
} 
to have a winning record. Therefore, a 7 th win in a season usually secures a post-season spot, while a 7 th loss almost always means that the team will not participate in a bowl game.

Results of these regressions are reported in the far right columns of the Table 5.3 , just left of the baseline coefficients. They seem to suggest that the effect of important games is stronger than other games. However, as in the two cases above, the particular coefficients are not statistically different.

\section{Robustness and Sensitivity Checks}

This section presents results of several types of robustness and sensitivity analysis. We begin with exploration of the cutoff values that were selected for the baseline estimation. The section then proceeds with discussion of the composition of the control group, functional form specification, and placebo tests.

\subsection{Selection of Cutoff Values}

The results of several robustness checks on the coefficient of unexpected wins in the post-game window are presented in following sections. Due to space constraints, results in this section are presented graphically. Full scale tables reporting estimates from these regressions are space-demanding and are available upon request. The controls maintain their approximate significance levels throughout all robust estimations. The coefficient on unexpected losses remains insignificant.

\subsubsection{Sample Restriction Based on Like Percentage}

The results covering the sensitivity of our baseline regression to the selection of the cutoff percentage rate for sample restriction are presented in Figure 4. 


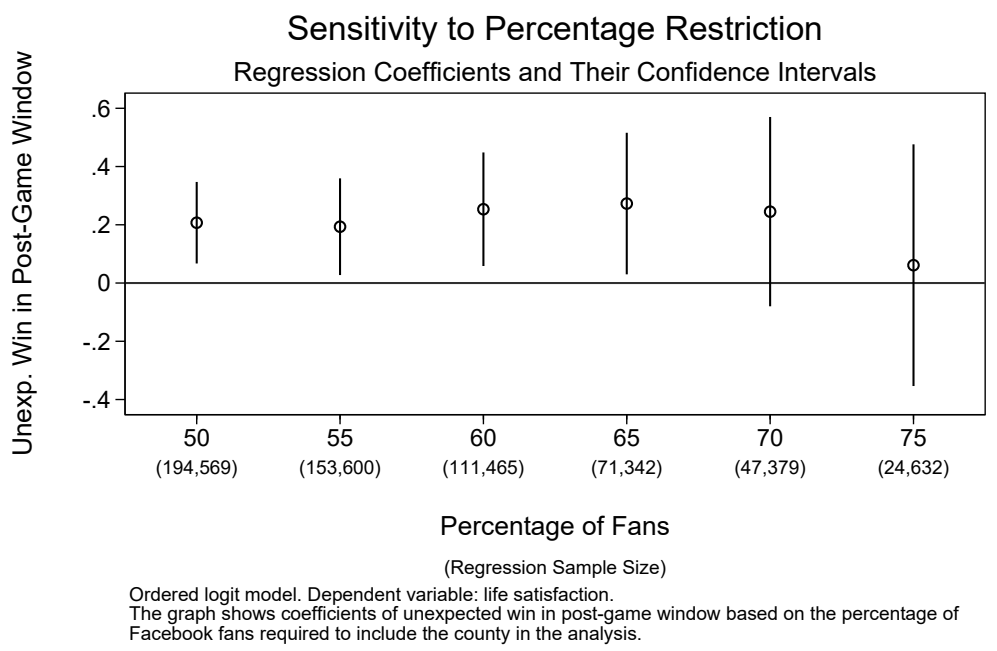

Figure 4: Sensitivity to Percentage of Likes

We can see that increasing the cutoff rate generally leads to a higher reported point estimate, suggesting the idea that the effect is stronger in areas where the dominant team has higher support. If, however, it reaches an area above $70 \%$, the number of observations declines as the sample size decreases substantially, in turn harming statistical inference and expanding standard errors of regression coefficients. ${ }^{30}$

\subsubsection{Point Difference For Unexpected Results}

In order to check for potential sensitivity to how unexpected the outcome is, we adapt several changes of the default cutoff. The results are presented in Figure 5.

The figure suggests that the stronger the surprise is, the stronger the relationship is. Moreover, the coefficient is statistically significant regardless of which value of the cutoff spread is chosen.

\footnotetext{
${ }^{30}$ The largest value of like rate is just under $87 \%$ of likes and less than $5 \%$ of observations lies in regions with more than $75 \%$ of likes.
} 


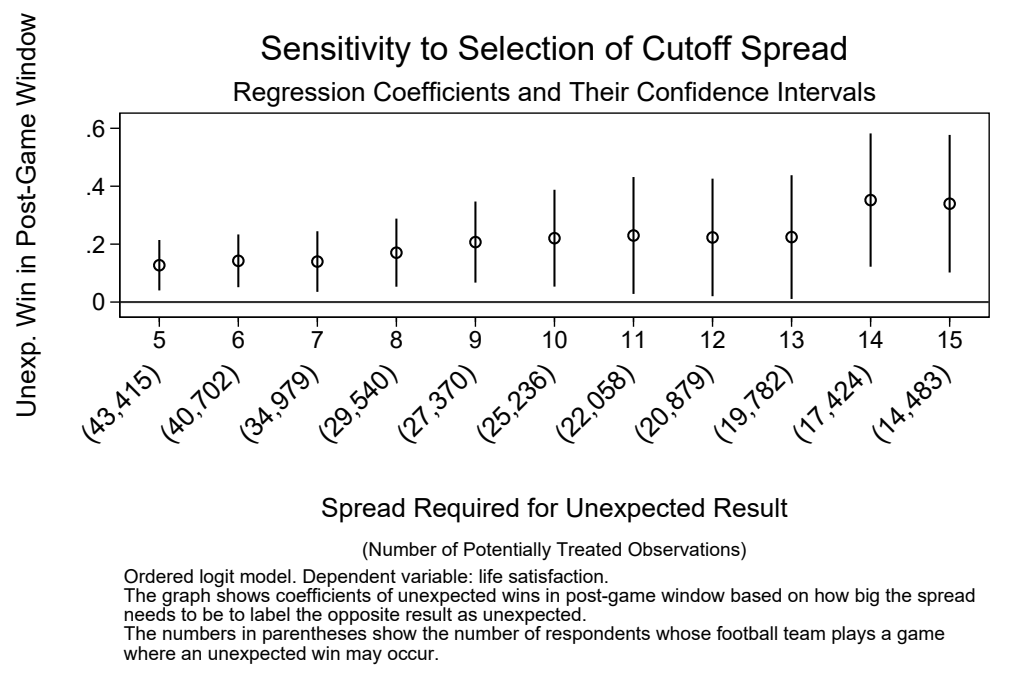

Figure 5: Sensitivity to Value of Spread

\subsubsection{Post-Game Window Length}

The results of regressions depending on the length of the post-game window are presented in Figure 6. The effects for one and two day periods are arguably not identified due to a small number of observations in the treatment group (hence the larger standard error). The results also show that the effect does not disappear even after expanding the post-game window length to five days.

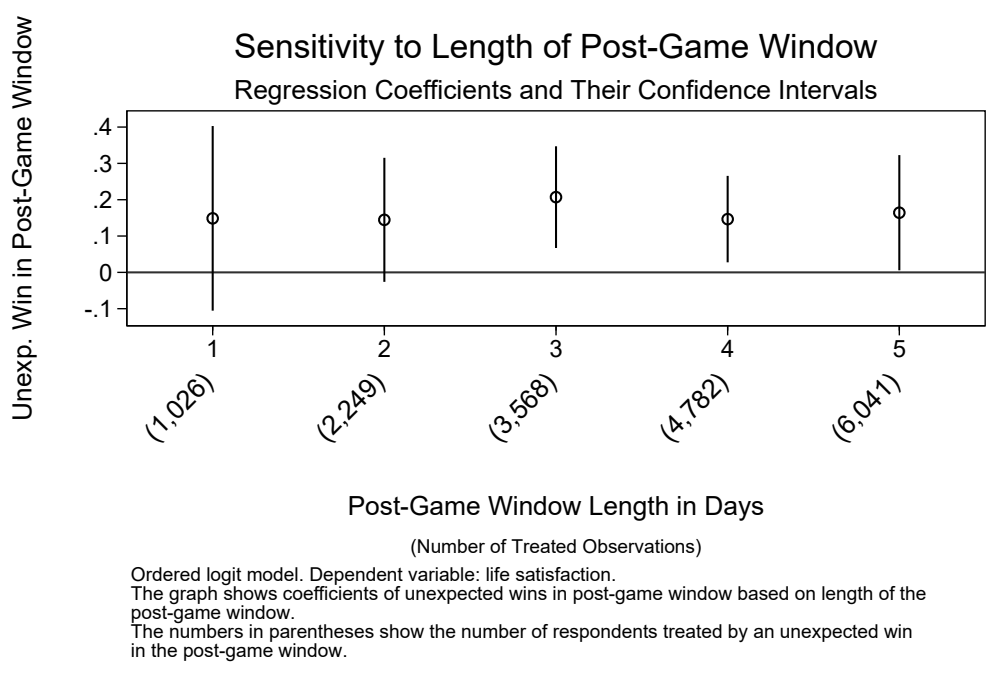

Figure 6: Sensitivity to Length of Post-game Window 


\subsection{Composition of the Control Group}

The regression design described in Section 4 carries a glitch in the sense that the first three days after a game are included in the treatment group, while the fourth and following days enter the control group. Therefore, there is a danger of the benchmark level of life satisfaction being influenced by the treatment variable. In order to examine whether this is an issue, estimation of the baseline model was repeated using different sample restrictions based on whether there was a previous unexpected result that could possibly have influenced the control group.

The results are shown in Table 6.1. The first column shows results from the baseline estimation and is therefore present for comparison reasons only. The second column excludes games which ended with an unexpected result in the two weeks after the previous unexpected result. The third column excludes all observations that happened after the first unexpected result in a given season. Finally, the fourth column includes only weeks before and after an unexpected result which occurred at least two weeks after the previous unexpected result.

The similarity of all coefficients in these regressions suggests that there is only a very limited issue with the survey design in the sense of control group composition.

\subsection{Functional Form Specification}

While previous sections look at the sensitivity of the main analysis in terms of selecting cutoff values that inevitably remain arbitrary, this section leaves these cutoff values at their baseline levels and explores a potential threat of a different kind. Specifically, as the ordered logit model is heavily dependent on its functional form specification, this section runs an alternative version of the analysis. 
Table 6.1: Control Group Composition: Ordered Logit Coefficients Dependent Variable: Life Satisfaction

\begin{tabular}{|c|c|c|c|c|}
\hline & $\mathrm{All}^{\mathrm{A}}$ & Excl Week $^{\mathrm{B}}$ & Excl All ${ }^{\mathrm{C}}$ & $\operatorname{Incl}^{\mathrm{D}}$ \\
\hline$\lambda_{1}:$ Unexp. Win $^{1} \times$ Window $^{2}$ & $\begin{array}{l}.207^{* * *} \\
(0.07)\end{array}$ & $\begin{array}{l}.196^{* * *} \\
(0.07)\end{array}$ & $\begin{array}{l}.206^{* *} \\
(0.08)\end{array}$ & $\begin{array}{c}.257^{* *} \\
(0.12)\end{array}$ \\
\hline$\lambda_{2}:$ Unexp. Loss $^{1} \times$ Window $^{2}$ & $\begin{array}{c}7.0 \mathrm{e}-03 \\
(0.06)\end{array}$ & $\begin{array}{c}-6.9 \mathrm{e}-03 \\
(0.06)\end{array}$ & $\begin{array}{l}-.011 \\
(0.07)\end{array}$ & $\begin{array}{l}-.022 \\
(0.12)\end{array}$ \\
\hline$\gamma_{1}:$ Unexpected $\mathrm{Win}^{1}$ & $\begin{array}{l}-.053 \\
(0.04)\end{array}$ & $\begin{array}{l}-.063 \\
(0.05)\end{array}$ & $\begin{array}{l}-.085 \\
(0.05)\end{array}$ & $\begin{array}{l}-.118 \\
(0.08)\end{array}$ \\
\hline$\gamma_{2}:$ Unexpected Loss ${ }^{1}$ & $\begin{array}{c}.021 \\
(0.04)\end{array}$ & $\begin{array}{c}.023 \\
(0.04)\end{array}$ & $\begin{array}{c}.033 \\
(0.05)\end{array}$ & $\begin{array}{c}.037 \\
(0.09)\end{array}$ \\
\hline$\delta_{1}:$ Win & $\begin{array}{c}-8.0 \mathrm{e}-03 \\
(0.01)\end{array}$ & $\begin{array}{c}-7.4 \mathrm{e}-03 \\
(0.02)\end{array}$ & $\begin{array}{c}1.9 \mathrm{e}-04 \\
(0.02)\end{array}$ & $\begin{array}{l}-.022 \\
(0.07)\end{array}$ \\
\hline$\delta_{2}:$ Post-Game Window $^{2}$ & $\begin{array}{c}7.5 \mathrm{e}-03 \\
(0.02)\end{array}$ & $\begin{array}{c}5.9 \mathrm{e}-03 \\
(0.02)\end{array}$ & $\begin{array}{c}.016 \\
(0.02)\end{array}$ & $\begin{array}{l}-.054 \\
(0.09)\end{array}$ \\
\hline$\delta_{3}:$ Win $\times$ Post-Game Window ${ }^{2}$ & $\begin{array}{l}-.028 \\
(0.02)\end{array}$ & $\begin{array}{l}-.028 \\
(0.02)\end{array}$ & $\begin{array}{l}-.042^{*} \\
(0.02)\end{array}$ & $\begin{array}{c}.014 \\
(0.11)\end{array}$ \\
\hline Observations & 194569 & 183929 & 146590 & 16867 \\
\hline
\end{tabular}

Coefficients from regressions with alternative definition of control groups described below. All columns include full set of controls, weekly fixed effects, and state-team fixed effects. Standard errors adjusted for clusters on the county level in parentheses.

Significance levels: ${ }^{*} p<0.10,{ }^{* *} p<0.05,{ }^{* * *} p<0.01$

A Baseline estimation.

B Excludes the week after an unexpected result.

C Excludes all observations after the first unexpected result in the season.

D Includes only the weeks before and after an unexpected result.

${ }^{1} \mathrm{~A}$ win by a team expected to lose by at least 9 points given the pre-game betting spread.

2 Post-game window is a period of three days after the last game was played.

Source: Estimation of the ordered linear probability model. 
As shown in Table 3.2, 94.3\% of answers to the life satisfaction question lie in categories "Satisfied" and "Very Satisfied". This opens a possibility to check for a functional form misspecification in the sense that the effect is very likely identified through transition between the top two categories. Therefore, we excluded the observations in which life satisfaction was reported as "Very Dissatisfied" or "Dissatisfied" and then fit a linear probability model on the resulting binary variable equal to 1 for the "Very Satisfied" answer.

Coefficients on football variables from this estimation are reported in Table $6.2 .{ }^{31}$ The results are qualitatively very similar to results of the baseline model, therefore we can conclude that functional form misspecification does not present a serious thread in our model.

\subsection{Placebo Games}

Even though we performed robustness checks, the individual heterogeneity present due to the repeated cross-sectional nature of the dataset inevitably leads to a danger of biased coefficients. Therefore, following Doerrenberg \& Siegloch (2014), we switched all the game results by six months backward and checked whether our regressions still carried their significance. ${ }^{32}$ In case the results still proved significant, this would suggest that the effect in fact lies in some unobservable factors that were not controlled for in our regression.

The results of football related coefficients from these placebo regressions are reported in Table 6.3. ${ }^{33}$ The disappearance of the effect supports the overall conclusion

\footnotetext{
${ }^{31}$ Full results are shown in the Appendix in Table A.4.

${ }^{32}$ Specifically, all games were switched by 26 weeks in order to keep the day of the week identical for all games in question.

${ }^{33}$ See Table A.5 in the appendix for complete results of placebo regressions.
} 
Table 6.2: Linear Probability Model Coefficients

Dependent Variable: 1 if Life Satisfaction reported as "Very Satisfied"

\begin{tabular}{|c|c|c|c|c|}
\hline & (1) & $(2)$ & $(3)$ & $(4)$ \\
\hline$\lambda_{1}:$ Unexp. Win $^{1} \times$ Window $^{2}$ & $\begin{array}{l}.036^{* *} \\
(0.02)\end{array}$ & $\begin{array}{l}.039^{* *} \\
(0.02)\end{array}$ & $\begin{array}{c}.038^{* *} \\
(0.02)\end{array}$ & $\begin{array}{l}.037^{* *} \\
(0.02)\end{array}$ \\
\hline$\lambda_{2}:$ Unexp. Loss $^{1} \times$ Window $^{2}$ & $\begin{array}{c}.017 \\
(0.01)\end{array}$ & $\begin{array}{c}.014 \\
(0.01)\end{array}$ & $\begin{array}{c}.012 \\
(0.01)\end{array}$ & $\begin{array}{c}.012 \\
(0.01)\end{array}$ \\
\hline$\gamma_{1}:$ Unexpected $\mathrm{Win}^{1}$ & $\begin{array}{c}-7.5 \mathrm{e}-03 \\
(0.01)\end{array}$ & $\begin{array}{l}-.016 \\
(0.01)\end{array}$ & $\begin{array}{l}-.015 \\
(0.01)\end{array}$ & $\begin{array}{c}-.01 \\
(0.01)\end{array}$ \\
\hline$\gamma_{2}:$ Unexpected Loss ${ }^{1}$ & $\begin{array}{c}9.6 \mathrm{e}-04 \\
(0.01)\end{array}$ & $\begin{array}{c}1.1 \mathrm{e}-03 \\
(0.01)\end{array}$ & $\begin{array}{c}1.9 \mathrm{e}-03 \\
(0.01)\end{array}$ & $\begin{array}{c}-6.0 \mathrm{e}-04 \\
(0.01)\end{array}$ \\
\hline$\delta_{1}:$ Win & $\begin{array}{c}-4.3 \mathrm{e}-03 \\
(0.00)\end{array}$ & $\begin{array}{c}-2.2 \mathrm{e}-03 \\
(0.00)\end{array}$ & $\begin{array}{c}-2.0 \mathrm{e}-03 \\
(0.00)\end{array}$ & $\begin{array}{c}-3.1 \mathrm{e}-03 \\
(0.00)\end{array}$ \\
\hline$\delta_{2}:$ Post-Game Window ${ }^{2}$ & $\begin{array}{c}3.5 \mathrm{e}-03 \\
(0.00)\end{array}$ & $\begin{array}{c}-1.8 \mathrm{e}-03 \\
(0.00)\end{array}$ & $\begin{array}{c}-8.0 \mathrm{e}-04 \\
(0.00)\end{array}$ & $\begin{array}{c}1.9 \mathrm{e}-03 \\
(0.00)\end{array}$ \\
\hline$\delta_{3}:$ Win $\times$ Post-Game Window ${ }^{2}$ & $\begin{array}{c}-4.6 \mathrm{e}-03 \\
(0.01)\end{array}$ & $\begin{array}{c}-2.6 \mathrm{e}-03 \\
(0.01)\end{array}$ & $\begin{array}{c}-3.2 \mathrm{e}-03 \\
(0.01)\end{array}$ & $\begin{array}{c}-6.6 \mathrm{e}-03 \\
(0.01)\end{array}$ \\
\hline Controls $^{3}$ & No & Yes & Yes & Yes \\
\hline Weekly fixed effects & No & No & Yes & Yes \\
\hline State-team fixed effects & No & No & No & Yes \\
\hline Observations & 185539 & 183167 & 183167 & 183167 \\
\hline
\end{tabular}

Dependent variable coded as 1 if life satisfaction answered as "Very satisfied" and 0 as "Satisfied". Answers "Dissatisfied" and "Very Dissatisfied" dropped from the dataset.

Standard errors adjusted for clusters on the county level in parentheses.

Significance levels: ${ }^{*} p<0.10,{ }^{* *} p<0.05,{ }^{* * *} p<0.01$

${ }^{1} \mathrm{~A}$ win by a team expected to lose by at least 9 points given the pre-game betting spread.

2 The post-game window is a period of three days after the last game was played.

${ }^{3}$ Controls include individual's personal, economic and health variables. See Appendix A for details.

Source: Estimation of the ordered linear probability model. 
Table 6.3: Placebo Regression: Ordered Logit Coefficients Dependent Variable: Life Satisfaction

\begin{tabular}{|c|c|c|c|c|}
\hline & (1) & $(2)$ & (3) & (4) \\
\hline$\lambda_{1}:$ Unexp. Win $^{1} \times$ Window $^{2}$ & $\begin{array}{c}.024 \\
(0.07)\end{array}$ & $\begin{array}{c}.056 \\
(0.07)\end{array}$ & $\begin{array}{c}.053 \\
(0.08)\end{array}$ & $\begin{array}{c}.037 \\
(0.07)\end{array}$ \\
\hline$\lambda_{2}:$ Unexp. Loss $^{1} \times$ Window $^{2}$ & $\begin{array}{c}.054 \\
(0.05)\end{array}$ & $\begin{array}{c}.037 \\
(0.05)\end{array}$ & $\begin{array}{c}.021 \\
(0.05)\end{array}$ & $\begin{array}{c}.02 \\
(0.05)\end{array}$ \\
\hline$\gamma_{1}:$ Unexpected $\mathrm{Win}^{1}$ & $\begin{array}{c}.021 \\
(0.03)\end{array}$ & $\begin{array}{l}-.014 \\
(0.04)\end{array}$ & $\begin{array}{c}7.1 \mathrm{e}-03 \\
(0.04)\end{array}$ & $\begin{array}{c}.027 \\
(0.04)\end{array}$ \\
\hline$\gamma_{2}:$ Unexpected Loss ${ }^{1}$ & $\begin{array}{c}-4.0 \mathrm{e}-03 \\
(0.03)\end{array}$ & $\begin{array}{c}-7.6 \mathrm{e}-03 \\
(0.04)\end{array}$ & $\begin{array}{c}4.8 \mathrm{e}-04 \\
(0.04)\end{array}$ & $\begin{array}{c}-1.6 \mathrm{e}-03 \\
(0.04)\end{array}$ \\
\hline$\delta_{1}:$ Win & $\begin{array}{l}-.022^{*} \\
(0.01)\end{array}$ & $\begin{array}{l}-.018 \\
(0.02)\end{array}$ & $\begin{array}{l}-.017 \\
(0.02)\end{array}$ & $\begin{array}{c}-9.1 \mathrm{e}-03 \\
(0.01)\end{array}$ \\
\hline$\delta_{2}:$ Post-Game Window ${ }^{2}$ & $\begin{array}{l}-.015 \\
(0.02)\end{array}$ & $\begin{array}{l}-.045^{* * *} \\
(0.02)\end{array}$ & $\begin{array}{l}-.04^{* *} \\
(0.02)\end{array}$ & $\begin{array}{l}-.021 \\
(0.02)\end{array}$ \\
\hline$\delta_{3}:$ Win $\times$ Post-Game Window ${ }^{2}$ & $\begin{array}{c}.047^{* *} \\
(0.02)\end{array}$ & $\begin{array}{l}.062^{* * *} \\
(0.02)\end{array}$ & $\begin{array}{l}.059 \text { *** } \\
(0.02)\end{array}$ & $\begin{array}{c}.038^{*} \\
(0.02)\end{array}$ \\
\hline Controls $^{3}$ & No & Yes & Yes & Yes \\
\hline Weekly fixed effects & No & No & Yes & Yes \\
\hline State-team fixed effects & $\mathrm{No}$ & No & $\mathrm{No}$ & Yes \\
\hline Observations & 193822 & 191350 & 191350 & 191350 \\
\hline
\end{tabular}

Dates of all games switched by six months backward to obtain placebo effects.

Standard errors adjusted for clusters on the county level in parentheses.

Significance levels: ${ }^{*} p<0.10,{ }^{* *} p<0.05,{ }^{* * *} p<0.01$

${ }^{1} \mathrm{~A}$ win by a team expected to lose by at least 9 points given the pre-game betting spread.

2 The post-game window is a period of three days after the last game was played.

${ }^{3}$ Controls include individual's personal, economic and health variables. See Appendix A for details.

Source: Estimation of the ordered logit model. 
that the relationship between unexpected wins and life satisfaction is indeed present in the data.

\section{Conclusions}

To our knowledge, this study is the first to find statistically significant effects of sports results on a long-term measure of life satisfaction in a large scale dataset. Specifically, it presents evidence of an increase in life satisfaction scores following an unexpected win by the local college football team in the three days after the game. No effects are found for unexpected losses or for any results which can not be viewed as surprising based on the pre-game betting market.

The identified effect from our baseline regression suggests that the probability of respondents reporting the highest category of life satisfaction rises by approximately 4.5\% following an unexpected win when surveyed within three days after the game. Moreover, this effect is likely biased towards zero due to the presence of measurement error. Back of the envelope calculation suggests that this effect would in fact be stronger than $10 \%$ in absence of this measurement error.

The decomposition of the results reveals that the effect is mainly driven by home games rather than those played on the road. Moreover, the effect is statistically significant in counties which are mainly Republican, and is insignificant in Democratic counties. The analysis also reveals statistically weak suggestions that the effect is stronger for women, college alumni, non-metropolitan areas, and for important games. The analysis for strength of surprise needed to label the game result unexpected suggests that more surprising results are connected to stronger reactions, which could aid understanding why fans stick to unsuccessful teams over long time 
periods.

Nevertheless, although the effect is sizable ex-post after an unexpected win, it is important to note that its overall magnitude is negligible. Even though the effect is not zero-sum due to presence of reactions to unexpected wins but not losses, the overall dataset mean is distorted upwards by a fraction of 0.0006 of the data's standard deviation. Thus, while the effect is statistically significant and precisely estimated, it is too small to present issues for the measure of life satisfaction in the sense of comparing its reported values through time and/or region.

The results are robust to functional form specification, control group definition, restriction on the strength of team support, level of surprise needed in order to designate a result unexpected, and the number of days we consider an individual to be potentially affected by the football game result. After switching dates of games out of the football season in order to test for a placebo effect, the relationship disappears, supporting the existence of the effect.

Note that there is one explanation for the effect that our study was not able to examine. Specifically, the dataset used in the analysis only asks the respondent a question about life satisfaction, without previously examining her momentary happiness. This causes a danger of misreporting life satisfaction, in the sense of respondents being unaware that their current mood may alter their answer. Future research is needed to disentangle these two possibilities. 


\section{References}

Agarwal, S., Duchin, R., \& Sosyura, D. (2013). In the Mood for a Loan: The Causal Effect of Sentiment on Credit Origination.

Ahlfeldt, G. M. \& Kavetsos, G. (2011). Form or Function? The Impact of New Football Stadia on Property Prices in London. SERC Discussion Papers 0087, Spatial Economics Research Centre, LSE.

Ahlfeldt, G. M. \& Maennig, W. (2010). Impact of sports arenas on land values: evidence from berlin. The Annals of Regional Science, 44(2), 205-227.

Ansolabehere, S., Rodden, J., \& Snyder, James M., J. (2006). Purple America. Journal of Economic Perspectives, 20(2), 97-118.

Blanchflower, D. G. \& Oswald, A. J. (2008). Is well-being U-shaped over the life cycle? Social Science 6 Medicine, 66(8), 1733-1749.

Blanchflower, D. G., Oswald, A. J., \& Stewart-Brown, S. (2013). Is Psychological Well-Being Linked to the Consumption of Fruit and Vegetables? Social Indicators Research, $114(3), 785-801$.

Boyd-Swan, C. \& Herbst, C. M. (2012). Pain at the pump: Gasoline prices and subjective well-being. Journal of Urban Economics, 72(2 - 3), 160 - 175.

Card, D. \& Dahl, G. B. (2011). Family Violence and Football: The Effect of Unexpected Emotional Cues on Violent Behavior. The Quarterly Journal of Economics, $126(1), 103-143$. 
Chen, D. L. (2016). This Morning's Breakfast, Last Night's Game: Detecting Extraneous Influences on Judging. Social Science Research Network Working Paper Series.

Coates, D. \& Humphreys, B. R. (2008). Do Economists Reach a Conclusion on Subsidies for Sports Franchises, Stadiums, and Mega-Events? Econ Journal Watch, 5(3), 294-315.

Deaton, A. \& Stone, A. A. (2013). Do context effects limit the usefulness of selfreported wellbeing measures? RPDS Working Papers 288, Princeton University.

Deaton, A. \& Stone, A. A. (2014). Evaluative and hedonic wellbeing among those with and without children at home. Proceedings of the National Academy of Sciences, $111(4), 1328-1333$.

Diener, E., Inglehart, R., \& Tay, L. (2013). Theory and Validity of Life Satisfaction Scales. Social Indicators Research, 112(3), 497-527.

Doerrenberg, P. \& Siegloch, S. (2014). Is soccer good for you? The motivational impact of big sporting events on the unemployed. Economics Letters, 123(1), 66 $-69$.

Dolan, P., Peasgood, T., \& White, M. (2008). Do we really know what makes us happy? A review of the economic literature on the factors associated with subjective well-being. Journal of Economic Psychology, 29(1), 94 - 122.

Drake, M. S., Gee, K. H., \& Thornock, J. R. (2016). March Market Madness: 
The Impact of Value-Irrelevant Events on the Market Pricing of Earnings News. Contemporary Accounting Research, 33(1), 172-203.

Edmans, A., García, D., \& Norli, Ø. (2007). Sports Sentiment and Stock Returns. The Journal of Finance, 62(4), 1967-1998.

Fair, R. C. \& Oster, J. F. (2007). College Football Rankings and Market Efficiency. Journal of Sports Economics, 8(1), 3-18.

Fernquist, R. M. (2000). An aggregate analysis of professional sports, suicide, and homicide rates: 30 u.s. metropolitan areas, 1971-1990. Aggression and Violent Behavior, 5(4), $329-341$.

Haucap, J. \& Heimeshoff, U. (2014). The happiness of economists: Estimating the causal effect of studying economics on subjective well-being. International Review of Economics Education.

Healy, A. J., Malhotra, N., \& Mo, C. H. (2010). Irrelevant events affect voters' evaluations of government performance. Proceedings of the National Academy of Sciences, 107(29), 12804-12809.

Huang, H. \& Humphreys, B. R. (2012). Sports participation and happiness: Evidence from US microdata. Journal of Economic Psychology, 33(4), 776 - 793.

Humphreys, B. R. \& Nowak, A. (2015). Professional Sports Facilities, Teams and Property Values: Evidence from Seattle's Key Arena. Working Papers 15-06, Department of Economics, West Virginia University. 
Jones, M. V., Coffee, P., Sheffield, D., Yangüez, M., \& Barker, J. B. (2012). Just a game? changes in english and spanish soccer fans' emotions in the 2010 world cup. Psychology of Sport and Exercise, 13(2), $162-169$.

Kavetsos, G. \& Szymanski, S. (2010). National well-being and international sports events. Journal of Economic Psychology, 31(2), 158-171.

Kerr, J. H., Wilson, G. V., Nakamura, I., \& Sudo, Y. (2005). Emotional dynamics of soccer fans at winning and losing games. Personality and Individual Differences, $38(8), 1855-1866$.

Koszegi, B. \& Rabin, M. (2006). A Model of Reference-Dependent Preferences. The Quarterly Journal of Economics, 121(4), 1133-1165.

Krueger, A. B. \& Schkade, D. A. (2008). The reliability of subjective well-being measures. Journal of Public Economics, 92(8-9), 1833 - 1845. Special Issue: Happiness and Public Economics.

Lucas, R. E. \& Lawless, N. M. (2013). Does life seem better on a sunny day? Examining the association between daily weather conditions and life satisfaction judgments. Journal of Personality and Social Psychology, 104(5), 872 - 884 .

Rees, D. I. \& Schnepel, K. T. (2009). College Football Games and Crime. Journal of Sports Economics, 10(1), 68-87.

Sauer, R. D. (1998). The economics of wagering markets. Journal of Economic Literature, 36(4), 2021-2064. 
Schmiedeberg, C. \& Schröder, J. (2014). Does weather really influence the measurement of life satisfaction? Social Indicators Research, 117(2), 387-399.

Schwarz, N. \& Clore, G. L. (1983). Mood, misattribution, and judgments of wellbeing: Informative and directive functions of affective states. Journal of Personality and Social Psychology, 45, $513-523$.

Schwarz, N., Strack, F., Kommer, D., \& Wagner, D. (1987). Soccer, rooms, and the quality of your life: Mood effects on judgments of satisfaction with life in general and with specific domains. European Journal of Social Psychology, 17(1), 69 79.

Song, C., Boulier, B. L., \& Stekler, H. O. (2007). The comparative accuracy of judgmental and model forecasts of American football games. International Journal of Forecasting, 23(3), 405-413.

Yechiam, E., Telpaz, A., \& Hochman, G. (2014). The complaint bias in subjective evaluations of incentives. Decision, 1(2), 147. 


\section{A Appendix A: Full Regression Results and Control Vari- ables}

The following pages show the description of control variables, their descriptive statis-

tics, and full regression results associated with regressions from Sections 5.1 and 6.4.

With some exceptions, these results are comparable to results found by previous research.

Table A.1: Description of Dummies from BRFFS Variables

\begin{tabular}{|c|c|c|}
\hline Variable & Survey Question & Coded as 1 if \\
\hline Children in household & $\begin{array}{l}\text { How many children less than } 18 \\
\text { years of age live in your house- } \\
\text { hold? }\end{array}$ & $\begin{array}{l}\text { there is at least one } \\
\text { child }\end{array}$ \\
\hline Marital status dummies & Are you: (marital status) & $\begin{array}{l}\text { Answer reflects the } \\
\text { dummy }\end{array}$ \\
\hline Employment status dummies & $\begin{array}{l}\text { Are you currently: (employ- } \\
\text { ment status) }\end{array}$ & $"$ \\
\hline Education dummies & $\begin{array}{l}\text { What is the highest grade or } \\
\text { year of school you completed? }\end{array}$ & $"$ \\
\hline Income dummies & $\begin{array}{l}\text { Is your annual household in- } \\
\text { come from all sources: }\end{array}$ & $"$ (plus missing) \\
\hline Physically exercising & $\begin{array}{l}\text { During the past month, other } \\
\text { than your regular job, did you } \\
\text { participate in any physical ac- } \\
\text { tivities or exercises such as run- } \\
\text { ning, calisthenics, golf, garden- } \\
\text { ing, or walking for exercise? }\end{array}$ & "yes" \\
\hline Limited in activity & $\begin{array}{l}\text { Are you limited in any way in } \\
\text { any activities because of physi- } \\
\text { cal, mental, or emotional prob- } \\
\text { lems? }\end{array}$ & "yes" \\
\hline Smoking dummies & $\begin{array}{l}\text { Do you now smoke cigarettes } \\
\text { every day, some days, or not at } \\
\text { all? }\end{array}$ & $\begin{array}{l}\text { Answer reflects the } \\
\text { dummy (plus miss- } \\
\text { ing) }\end{array}$ \\
\hline
\end{tabular}

Source: BRFSS and own calculation 
Table A.2: Descriptive Statistics of BRFSS Data

\begin{tabular}{|c|c|c|}
\hline & Mean & S.D. \\
\hline Life Satisfaction & 3.379 & 0.632 \\
\hline \multicolumn{3}{|l|}{ Personal demographics } \\
\hline Age in years & 54.936 & 16.691 \\
\hline Age in years (squared) & 3296.519 & 1843.746 \\
\hline Male & 0.374 & 0.484 \\
\hline Children in household & 0.292 & 0.455 \\
\hline \multicolumn{3}{|l|}{ Marital status dummies (baseline: Never married) } \\
\hline Married & 0.568 & 0.495 \\
\hline Divorced & 0.141 & 0.348 \\
\hline Widowed & 0.139 & 0.346 \\
\hline Separated & 0.021 & 0.143 \\
\hline A member of an unmarried couple & 0.021 & 0.143 \\
\hline \multicolumn{3}{|l|}{ Employment status dummies (baseline: Employed for wages) } \\
\hline Self-employed & 0.080 & 0.271 \\
\hline Out of work for more than 1 year & 0.020 & 0.141 \\
\hline Out of work for less than 1 year & 0.024 & 0.153 \\
\hline Homemaker & 0.082 & 0.274 \\
\hline Student & 0.017 & 0.130 \\
\hline Retired & 0.276 & 0.447 \\
\hline Unable to work & 0.072 & 0.258 \\
\hline \multicolumn{3}{|l|}{ Education dummies (baseline: High school graduate) } \\
\hline Never attended school or only kindergarten & 0.001 & 0.036 \\
\hline Grades 1 - 8 (Elementary) & 0.030 & 0.171 \\
\hline Grades 9 - 11 (Some high school) & 0.066 & 0.248 \\
\hline College 1 to 3 years (Some college or technical school) & 0.270 & 0.444 \\
\hline College 4 years or more (College graduate) & 0.319 & 0.466 \\
\hline \multicolumn{3}{|l|}{ Income dummies (baseline: $\$ 35,000$ to under $\$ 50,000$ ) } \\
\hline Annual household income under $\$ 10,000$ & 0.045 & 0.208 \\
\hline Annual household income $\$ 10,000$ to under $\$ 15,000$ & 0.054 & 0.226 \\
\hline Annual household income $\$ 15,000$ to under $\$ 20,000$ & 0.069 & 0.253 \\
\hline Annual household income $\$ 20,000$ to under $\$ 25,000$ & 0.089 & 0.285 \\
\hline Annual household income $\$ 25,000$ to under $\$ 35,000$ & 0.115 & 0.319 \\
\hline Annual household income $\$ 50,000$ to under $\$ 75,000$ & 0.145 & 0.352 \\
\hline Annual household income over $\$ 75,000$ & 0.213 & 0.409 \\
\hline Income info missing & 0.127 & 0.333 \\
\hline \multicolumn{3}{|l|}{ Health proxies } \\
\hline Physically exercising & 0.721 & 0.448 \\
\hline Limited in activity & 0.267 & 0.442 \\
\hline Smoking every day & 0.137 & 0.344 \\
\hline Smoking some days & 0.043 & 0.203 \\
\hline Smoking info missing & 0.530 & 0.499 \\
\hline
\end{tabular}

Source: BRFSS 
Table A.3: Ordered Logit Coefficients

Dependent variable: Life Satisfaction

\begin{tabular}{|c|c|c|c|}
\hline & $(1)$ & $(2)$ & (3) \\
\hline \multicolumn{4}{|l|}{ Football results } \\
\hline Unexp. Win $^{1} \times$ Window $^{2}$ & $\begin{array}{l}.212^{* * *} \\
(0.07)\end{array}$ & $\begin{array}{l}.204^{* * *} \\
(0.07)\end{array}$ & $\begin{array}{l}.207^{* * *} \\
(0.07)\end{array}$ \\
\hline Unexp. Loss ${ }^{1} \times$ Window $^{2}$ & $\begin{array}{l}.019 \\
(0.06)\end{array}$ & $\begin{array}{l}4.4 \mathrm{e}-03 \\
(0.06)\end{array}$ & $\begin{array}{l}7.0 \mathrm{e}-03 \\
(0.06)\end{array}$ \\
\hline Unexpected Win ${ }^{1}$ & $\begin{array}{l}-.08^{* *} \\
(0.04)\end{array}$ & $\begin{array}{l}-.067 \\
(0.04)\end{array}$ & $\begin{array}{l}-.053 \\
(0.04)\end{array}$ \\
\hline Unexpected Loss ${ }^{1}$ & $\begin{array}{l}.021 \\
(0.04)\end{array}$ & $\begin{array}{l}.032 \\
(0.04)\end{array}$ & $\begin{array}{l}.021 \\
(0.04)\end{array}$ \\
\hline$\delta_{-} 1:$ Win & $\begin{array}{c}-6.5 \mathrm{e}-03 \\
(0.02)\end{array}$ & $\begin{array}{c}-6.6 \mathrm{e}-03 \\
(0.02)\end{array}$ & $\begin{array}{c}-8.0 \mathrm{e}-03 \\
(0.01)\end{array}$ \\
\hline Post-Game Window ${ }^{2}$ & $\begin{array}{l}-.012 \\
(0.02)\end{array}$ & $\begin{array}{l}-5.5 \mathrm{e}-03 \\
(0.02)\end{array}$ & $\begin{array}{c}7.5 \mathrm{e}-03 \\
(0.02)\end{array}$ \\
\hline Win $\times$ Post-Game Window ${ }^{2}$ & $\begin{array}{l}-.012 \\
(0.02) \\
\end{array}$ & $\begin{array}{l}-.013 \\
(0.02) \\
\end{array}$ & $\begin{array}{l}-.028 \\
(0.02) \\
\end{array}$ \\
\hline \multicolumn{4}{|l|}{ Personal demographics } \\
\hline Age in years & $\begin{array}{l}-.017^{* * *} \\
(0.00)\end{array}$ & $\begin{array}{l}-.017^{* * *} \\
(0.00)\end{array}$ & $\begin{array}{l}-.018^{* * *} \\
(0.00)\end{array}$ \\
\hline Age in years (squared) & $\begin{array}{l}2.1 \mathrm{e}-04^{* * *} \\
(0.00)\end{array}$ & $\begin{array}{l}2.1 \mathrm{e}-04^{* * *} \\
(0.00)\end{array}$ & $\begin{array}{l}2.3 \mathrm{e}-04^{* * *} \\
(0.00)\end{array}$ \\
\hline Male & $\begin{array}{l}-.131^{* * *} \\
(0.01)\end{array}$ & $\begin{array}{l}-.131 * * * \\
(0.01)\end{array}$ & $\begin{array}{l}-.129 * * * \\
(0.01)\end{array}$ \\
\hline Children in household ${ }^{3}$ & $\begin{array}{l}-.117^{* * *} \\
(0.01) \\
\end{array}$ & $\begin{array}{l}-.117^{* * *} \\
(0.01) \\
\end{array}$ & $\begin{array}{l}-.115^{* * *} \\
(0.01) \\
\end{array}$ \\
\hline \multicolumn{4}{|l|}{ Marital status dummies (baseline: Never married) } \\
\hline Married & $\begin{array}{l}.62^{* * *} \\
(0.02)\end{array}$ & $\begin{array}{l}.622^{* * *} \\
(0.02)\end{array}$ & $\begin{array}{l}.609 * * * \\
(0.02)\end{array}$ \\
\hline Divorced & $\begin{array}{l}.026 \\
(0.02)\end{array}$ & $\begin{array}{l}.027 \\
(0.02)\end{array}$ & $\begin{array}{l}.017 \\
(0.02)\end{array}$ \\
\hline Widowed & & & \\
\hline Separated & $\begin{array}{l}-.22^{* * *} \\
(0.04)\end{array}$ & $\begin{array}{l}-.221^{* * *} \\
(0.04)\end{array}$ & $\begin{array}{l}-.244^{* * *} \\
(0.04)\end{array}$ \\
\hline A member of an unmarried couple & $\begin{array}{l}.17^{* * *} \\
(0.03)\end{array}$ & $\begin{array}{l}.17^{* * *} \\
(0.03)\end{array}$ & $\begin{array}{l}.182^{* * *} \\
(0.04) \\
\end{array}$ \\
\hline \multicolumn{4}{|l|}{ Employment status dummies (baseline: Employed for wages) } \\
\hline Self-employed & $\begin{array}{l}.124^{* * *} \\
(0.02)\end{array}$ & $\begin{array}{l}.126^{* * *} \\
(0.02)\end{array}$ & $\begin{array}{l}.122^{* * *} \\
(0.02)\end{array}$ \\
\hline Out of work for more than 1 year & $\begin{array}{l}-.571^{* * *} \\
(0.04)\end{array}$ & $\begin{array}{l}-.572^{* * *} \\
(0.04)\end{array}$ & $\begin{array}{l}-.573^{* * *} \\
(0.04)\end{array}$ \\
\hline Out of work for less than 1 year & $\begin{array}{l}-.592^{* * *} \\
(0.03)\end{array}$ & $\begin{array}{l}-.591^{* * *} \\
(0.03)\end{array}$ & $\begin{array}{l}-.584^{* * *} \\
(0.03)\end{array}$ \\
\hline Homemaker & $\begin{array}{l}.151^{* * *} \\
(0.02)\end{array}$ & $\begin{array}{l}.155^{* * *} \\
(0.02)\end{array}$ & $\begin{array}{l}.147^{* * *} \\
(0.02)\end{array}$ \\
\hline Student & $\begin{array}{l}.183^{* * *} \\
(0.04)\end{array}$ & $\begin{array}{l}.183^{* * *} \\
(0.04)\end{array}$ & $\begin{array}{l}.174^{* * *} \\
(0.04)\end{array}$ \\
\hline Retired & $\begin{array}{l}.221^{* * *} \\
(0.02)\end{array}$ & $\begin{array}{l}.224^{* * *} \\
(0.02)\end{array}$ & $\begin{array}{l}.212^{* * *} \\
(0.02)\end{array}$ \\
\hline Unable to work & $\begin{array}{l}-.49^{* * *} \\
(0.03)\end{array}$ & $\begin{array}{l}-.489^{* * *} \\
(0.03)\end{array}$ & $\begin{array}{l}-.507^{* * *} \\
(0.03) \\
\end{array}$ \\
\hline \multicolumn{4}{|c|}{$\begin{array}{l}\text { Significance levels: }{ }^{*} p<0.10,{ }^{* *} p<0.05,{ }^{* * *} p<0.01 \\
{ }^{1} \text { A win by a team expected to lose by at least } 9 \text { points given the pre-game betting spread. } \\
2 \text { The post-game window is a period of three days after the last game was played. } \\
{ }^{3} \text { Equal to } 1 \text { if there are children living in the household with the respondent. }\end{array}$} \\
\hline
\end{tabular}


Table A.3: Ordered Logit Coefficients (continued) Dependent Variable: Life Satisfaction

\begin{tabular}{|c|c|c|c|}
\hline \multicolumn{4}{|l|}{ Education dummies (baseline: High school graduate) } \\
\hline Never attended school or only kindergarten & $\begin{array}{l}-.076 \\
(0.15)\end{array}$ & $\begin{array}{l}-.078 \\
(0.15)\end{array}$ & $\begin{array}{l}-.087 \\
(0.15)\end{array}$ \\
\hline Grades 1 - 8 (Elementary) & $\begin{array}{l}-.101^{* * *} \\
(0.03)\end{array}$ & $\begin{array}{l}-.101^{* * *} \\
(0.03)\end{array}$ & $\begin{array}{l}-.129^{* * *} \\
(0.03)\end{array}$ \\
\hline Grades 9 - 11 (Some high school) & $\begin{array}{l}-.056^{* * *} \\
(0.02)\end{array}$ & $\begin{array}{l}-.056^{* * *} \\
(0.02)\end{array}$ & $\begin{array}{l}-.077^{* * *} \\
(0.02)\end{array}$ \\
\hline College 1 to 3 years (Some college or technical school) & $\begin{array}{c}.011 \\
(0.01)\end{array}$ & $\begin{array}{c}9.8 \mathrm{e}-03 \\
(0.01)\end{array}$ & $\begin{array}{c}8.3 \mathrm{e}-03 \\
(0.01)\end{array}$ \\
\hline College 4 years or more (College graduate) & $\begin{array}{l}.155^{* * *} \\
(0.01)\end{array}$ & $\begin{array}{l}.154^{* * *} \\
(0.01)\end{array}$ & $\begin{array}{l}.157^{* * *} \\
(0.01) \\
\end{array}$ \\
\hline \multicolumn{4}{|l|}{ Income dummies (baseline: $\$ 35,000$ to under $\$ 50,000$ ) } \\
\hline Annual household income under $\$ 10,000$ & $\begin{array}{l}-.482^{* * *} \\
(0.03)\end{array}$ & $\begin{array}{l}-.482^{* * *} \\
(0.03)\end{array}$ & $\begin{array}{l}-.504^{* * *} \\
(0.03)\end{array}$ \\
\hline Annual household income $\$ 10,000$ to under $\$ 15,000$ & $\begin{array}{l}-.407^{* * *} \\
(0.03)\end{array}$ & $\begin{array}{l}-.406^{* * *} \\
(0.03)\end{array}$ & $\begin{array}{l}-.423^{* * *} \\
(0.03)\end{array}$ \\
\hline Annual household income $\$ 15,000$ to under $\$ 20,000$ & $\begin{array}{l}-.292^{* * *} \\
(0.02)\end{array}$ & $\begin{array}{l}-.293^{* * *} \\
(0.02)\end{array}$ & $\begin{array}{l}-.311^{* * *} \\
(0.02)\end{array}$ \\
\hline Annual household income $\$ 20,000$ to under $\$ 25,000$ & $\begin{array}{l}-.259^{* * *} \\
(0.02)\end{array}$ & $\begin{array}{l}-.258^{* * *} \\
(0.02)\end{array}$ & $\begin{array}{l}-.266^{* * *} \\
(0.02)\end{array}$ \\
\hline Annual household income $\$ 25,000$ to under $\$ 35,000$ & $\begin{array}{l}-.173^{* * *} \\
(0.02)\end{array}$ & $\begin{array}{l}-.173^{* * *} \\
(0.02)\end{array}$ & $\begin{array}{l}-.176^{* * *} \\
(0.02)\end{array}$ \\
\hline Annual household income $\$ 50,000$ to under $\$ 75,000$ & $\begin{array}{l}.158^{* * *} \\
(0.02)\end{array}$ & $\begin{array}{l}.158^{* * *} \\
(0.02)\end{array}$ & $\begin{array}{l}.163^{* * *} \\
(0.02)\end{array}$ \\
\hline Annual household income over $\$ 75,000$ & $\begin{array}{l}.459^{* * *} \\
(0.02)\end{array}$ & $\begin{array}{l}.457^{* * *} \\
(0.02)\end{array}$ & $\begin{array}{l}.469^{* * *} \\
(0.02)\end{array}$ \\
\hline Income info missing & $\begin{array}{c}-.013 \\
(0.02) \\
\end{array}$ & $\begin{array}{r}-.015 \\
(0.02) \\
\end{array}$ & $\begin{array}{l}-.029 \\
(0.02) \\
\end{array}$ \\
\hline \multicolumn{4}{|l|}{ Health proxies } \\
\hline Physically exercising ${ }^{4}$ & $\begin{array}{l}.359^{* * *} \\
(0.01)\end{array}$ & $\begin{array}{l}.362^{* * *} \\
(0.01)\end{array}$ & $\begin{array}{l}.374^{* * *} \\
(0.01)\end{array}$ \\
\hline Limited in activity ${ }^{5}$ & $\begin{array}{l}-.724^{* * *} \\
(0.01)\end{array}$ & $\begin{array}{l}-.725^{* * *} \\
(0.01)\end{array}$ & $\begin{array}{l}-.724^{* * *} \\
(0.01)\end{array}$ \\
\hline Smoking every day & $\begin{array}{l}-.324^{* * *} \\
(0.02)\end{array}$ & $\begin{array}{l}-.323^{* * *} \\
(0.02)\end{array}$ & $\begin{array}{l}-.33^{* * *} \\
(0.02)\end{array}$ \\
\hline Smoking some days & $\begin{array}{l}-.226^{* * *} \\
(0.03)\end{array}$ & $\begin{array}{l}-.227^{* * *} \\
(0.03)\end{array}$ & $\begin{array}{l}-.234^{* * *} \\
(0.03)\end{array}$ \\
\hline Smoking info missing & $\begin{array}{l}.056^{* * *} \\
(0.01) \\
\end{array}$ & $\begin{array}{l}.055^{* * *} \\
(0.01) \\
\end{array}$ & $\begin{array}{l}.05^{* * *} \\
(0.01) \\
\end{array}$ \\
\hline cut1 & $\begin{array}{l}-4.65^{* * *} \\
(0.06)\end{array}$ & $\begin{array}{l}-4.65^{* * *} \\
(0.10)\end{array}$ & $\begin{array}{l}-4.76^{* * *} \\
(0.11)\end{array}$ \\
\hline cut2 & $\begin{array}{l}-2.9^{* * *} \\
(0.06)\end{array}$ & $\begin{array}{l}-2.9^{* * *} \\
(0.10)\end{array}$ & $\begin{array}{l}-3.01^{* * *} \\
(0.11)\end{array}$ \\
\hline cut3 & $\begin{array}{l}.449^{* * *} \\
(0.05)\end{array}$ & $\begin{array}{l}.453^{* * *} \\
(0.10)\end{array}$ & $\begin{array}{l}.347^{* * *} \\
(0.11)\end{array}$ \\
\hline Weekly fixed effects & No & Yes & Yes \\
\hline Team-State fixed effects & No & No & Yes \\
\hline Observations & 194569 & 194569 & 194569 \\
\hline
\end{tabular}


Table A.4: Linear Probability Model Coefficients

Dependent Variable: 1 if Life Satisfaction Reported to be "Very Satisfied"

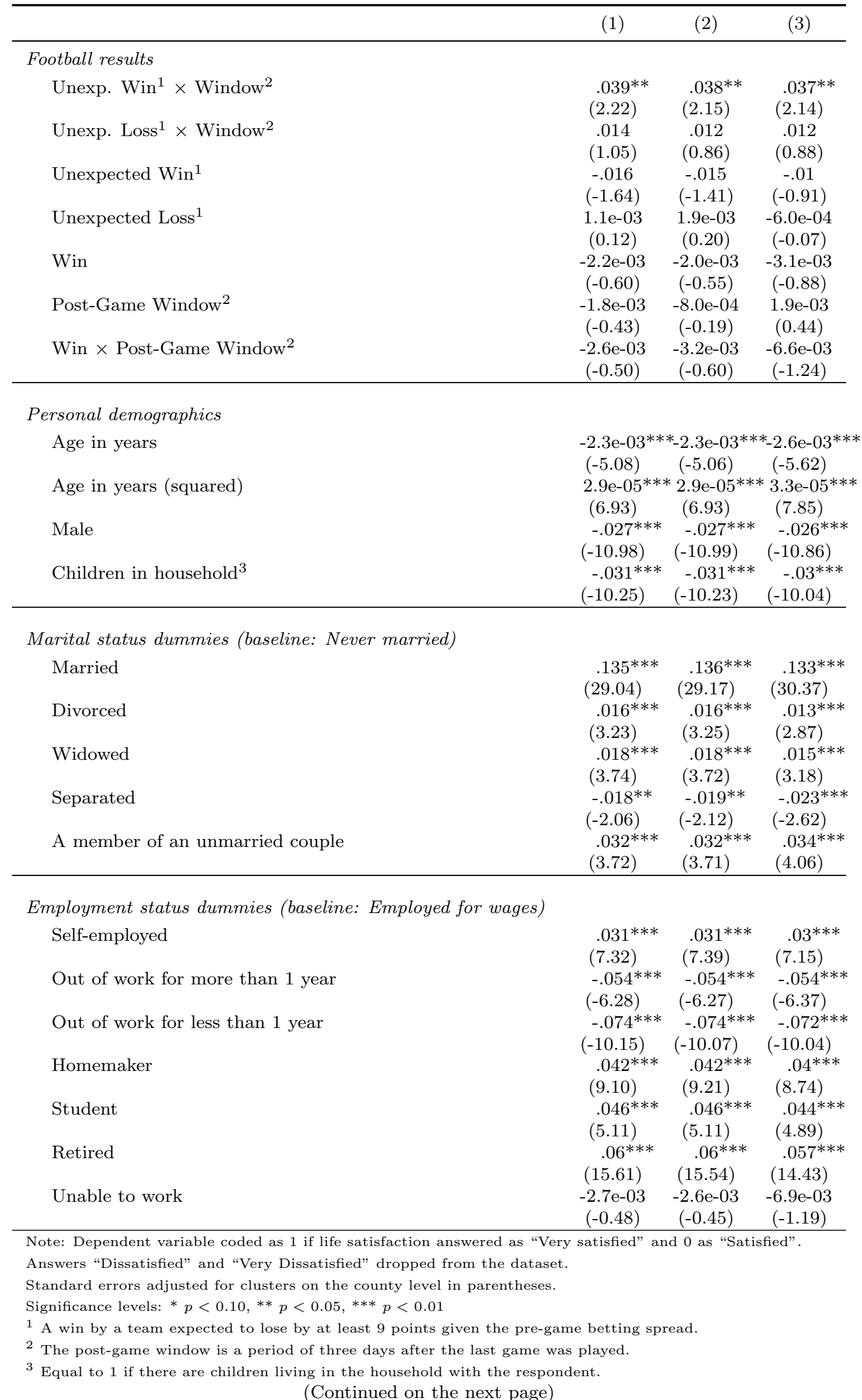

(Continued on the next page) 
Table A.4: Linear Probability Model Coefficients (continued) Dependent Variable: 1 if Life Satisfaction Reported to be "Very Satisfied"

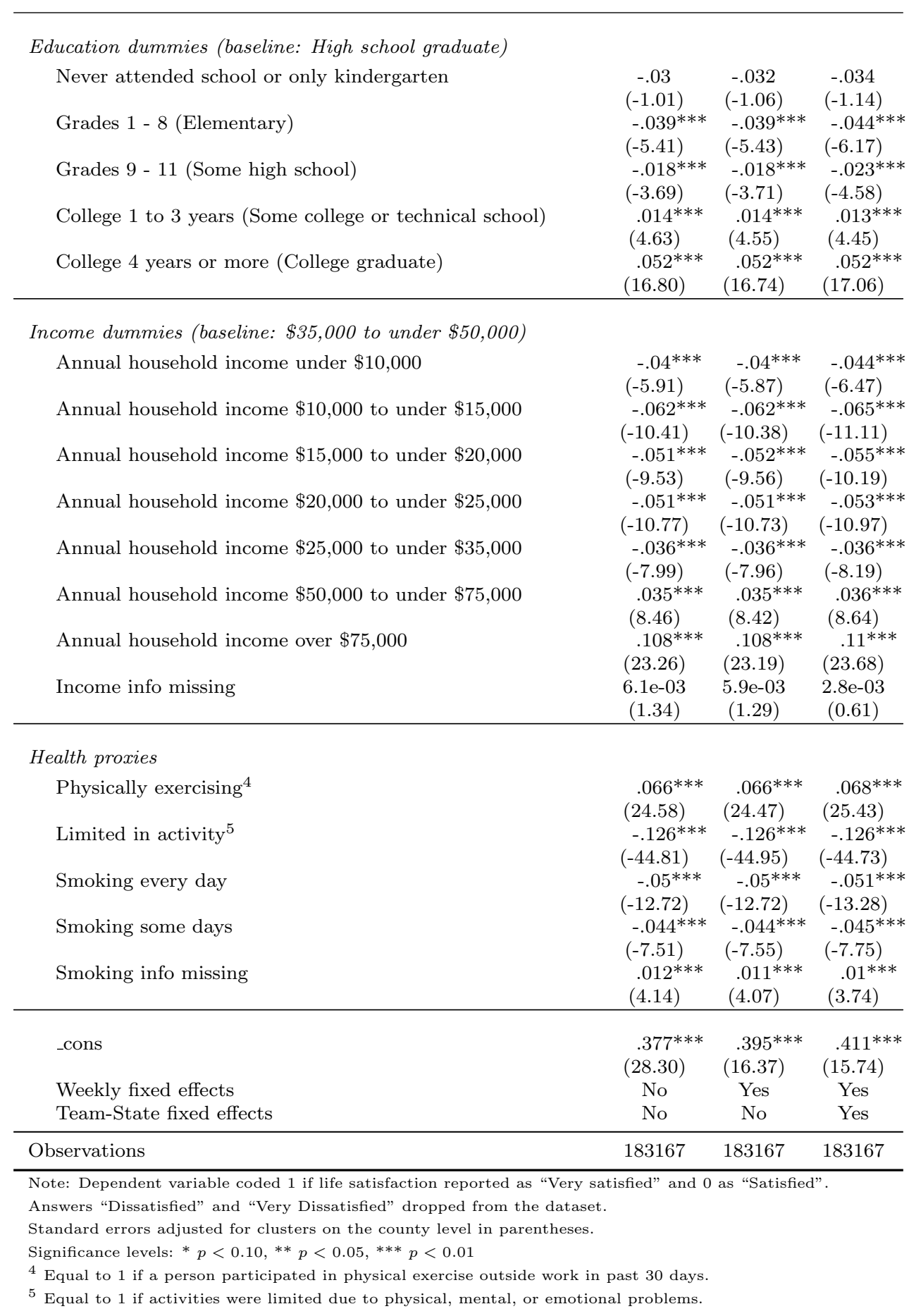


Table A.5: Placebo Regression: Ordered Logit Coefficients Dependent Variable: Life Satisfaction

\begin{tabular}{|c|c|c|c|}
\hline & (1) & $(2)$ & $(3)$ \\
\hline \multicolumn{4}{|l|}{ Football results } \\
\hline Unexp. Win $^{1} \times$ Window $^{2}$ & $\begin{array}{c}.056 \\
(0.07)\end{array}$ & $\begin{array}{c}.053 \\
(0.08)\end{array}$ & $\begin{array}{c}.037 \\
(0.07)\end{array}$ \\
\hline Unexp. $\operatorname{Loss}^{1} \times$ Window $^{2}$ & $\begin{array}{l}.037 \\
(0.05)\end{array}$ & $\begin{array}{c}.021 \\
(0.05)\end{array}$ & $\begin{array}{c}.02 \\
(0.05)\end{array}$ \\
\hline Unexpected Win ${ }^{1}$ & $\begin{array}{l}-.014 \\
(0.04)\end{array}$ & $\begin{array}{c}7.1 \mathrm{e}-03 \\
(0.04)\end{array}$ & $\begin{array}{l}.027 \\
(0.04)\end{array}$ \\
\hline Unexpected Loss ${ }^{1}$ & $\begin{array}{l}-7.6 \mathrm{e}-03 \\
(0.04)\end{array}$ & $\begin{array}{c}4.8 \mathrm{e}-04 \\
(0.04)\end{array}$ & $\begin{array}{c}-1.6 \mathrm{e}-03 \\
(0.04)\end{array}$ \\
\hline$\delta \_1:$ Win & $\begin{array}{l}-.018 \\
(0.02)\end{array}$ & $\begin{array}{l}-.017 \\
(0.02)\end{array}$ & $\begin{array}{c}-9.1 \mathrm{e}-03 \\
(0.01)\end{array}$ \\
\hline Post-Game Window ${ }^{2}$ & $\begin{array}{l}-.045^{* * *} \\
(0.02)\end{array}$ & $\begin{array}{l}-.04^{* *} \\
(0.02)\end{array}$ & $\begin{array}{l}-.021 \\
(0.02)\end{array}$ \\
\hline Win $\times$ Post-Game Window ${ }^{2}$ & $\begin{array}{l}.062^{* * *} \\
(0.02) \\
\end{array}$ & $\begin{array}{l}.059^{* * *} \\
(0.02) \\
\end{array}$ & $\begin{array}{l}.038^{*} \\
(0.02) \\
\end{array}$ \\
\hline \multicolumn{4}{|l|}{ Personal demographics } \\
\hline Age in years & $\begin{array}{l}-.02^{* * *} \\
(0.00)\end{array}$ & $\begin{array}{l}-.02^{* * *} \\
(0.00)\end{array}$ & $\begin{array}{l}-.022^{* * *} \\
(0.00)\end{array}$ \\
\hline Age in years (squared) & $\begin{array}{l}2.5 \mathrm{e}-04^{* * *} \\
(0.00)\end{array}$ & $\begin{array}{c}*^{*} .5 \mathrm{e}-04^{* * *} \\
(0.00)\end{array}$ & $\begin{array}{l}* 2.7 \mathrm{e}-04^{* *} \\
(0.00)\end{array}$ \\
\hline Male & $\begin{array}{l}-.15^{* * *} \\
(0.01)\end{array}$ & $\begin{array}{l}-.151^{* * *} \\
(0.01)\end{array}$ & $\begin{array}{l}-.147^{* * *} \\
(0.01)\end{array}$ \\
\hline Children in household ${ }^{3}$ & $\begin{array}{l}-.074^{* * *} \\
(0.01) \\
\end{array}$ & $\begin{array}{l}-.074^{* * *} \\
(0.01)\end{array}$ & $\begin{array}{l}-.073^{* * *} \\
(0.01) \\
\end{array}$ \\
\hline \multicolumn{4}{|c|}{ Marital status dummies (baseline: Never married) } \\
\hline Married & $\begin{array}{l}.593^{* * *} \\
(0.02)\end{array}$ & $\begin{array}{l}.593^{* * *} \\
(0.02)\end{array}$ & $\begin{array}{l}.586^{* * *} \\
(0.02)\end{array}$ \\
\hline Divorced & $\begin{array}{l}.027 \\
(0.02)\end{array}$ & $\begin{array}{l}.026 \\
(0.02)\end{array}$ & $\begin{array}{l}.019 \\
(0.02)\end{array}$ \\
\hline Widowed & $\begin{array}{l}.076^{* * *} \\
(0.02)\end{array}$ & $\begin{array}{l}.076^{* * *} \\
(0.02)\end{array}$ & $\begin{array}{l}.064^{* * *} \\
(0.02)\end{array}$ \\
\hline Separated & $\begin{array}{l}-.239^{* * *} \\
(0.04)\end{array}$ & $\begin{array}{l}-.239^{* * *} \\
(0.04)\end{array}$ & $\begin{array}{l}-.263^{* * *} \\
(0.04)\end{array}$ \\
\hline A member of an unmarried couple & $\begin{array}{l}.246^{* * *} \\
(0.04)\end{array}$ & $\begin{array}{l}.246^{* * *} \\
(0.04)\end{array}$ & $\begin{array}{l}.258^{* * *} \\
(0.04) \\
\end{array}$ \\
\hline \multicolumn{4}{|c|}{ Employment status dummies (baseline: Employed for wages) } \\
\hline Self-employed & $\begin{array}{l}.143^{* * *} \\
(0.02)\end{array}$ & $\begin{array}{l}.142^{* * *} \\
(0.02)\end{array}$ & $\begin{array}{l}.14^{* * *} \\
(0.02)\end{array}$ \\
\hline Out of work for more than 1 year & $\begin{array}{l}-.671^{* * *} \\
(0.04)\end{array}$ & $\begin{array}{l}-.673^{* * *} \\
(0.04)\end{array}$ & $\begin{array}{l}-.675^{* * *} \\
(0.04)\end{array}$ \\
\hline Out of work for less than 1 year & $\begin{array}{l}-.556^{* * *} \\
(0.03)\end{array}$ & $\begin{array}{l}-.551^{* * *} \\
(0.03)\end{array}$ & $\begin{array}{l}-.55^{* * *} \\
(0.03)\end{array}$ \\
\hline Homemaker & $\begin{array}{l}.126^{* * *} \\
(0.02)\end{array}$ & $\begin{array}{l}.128^{* * *} \\
(0.02)\end{array}$ & $\begin{array}{l}.122^{* * *} \\
(0.02)\end{array}$ \\
\hline Student & $\begin{array}{l}.159^{* * *} \\
(0.04)\end{array}$ & $\begin{array}{l}.161^{* * *} \\
(0.04)\end{array}$ & $\begin{array}{l}.158^{* * *} \\
(0.04)\end{array}$ \\
\hline Retired & $\begin{array}{l}.236^{* * *} \\
(0.02)\end{array}$ & $\begin{array}{l}.239^{* * *} \\
(0.02)\end{array}$ & $\begin{array}{l}.226^{* * *} \\
(0.02)\end{array}$ \\
\hline Unable to work & $\begin{array}{l}-.543^{* * *} \\
(0.03)\end{array}$ & $\begin{array}{l}-.539^{* * *} \\
(0.03)\end{array}$ & $\begin{array}{l}-.56^{* * *} \\
(0.03)\end{array}$ \\
\hline \multicolumn{4}{|c|}{$\begin{array}{l}\text { Significance levels: } * p<0.10,{ }^{* *} p<0.05,{ }^{* * *} p<0.01 \\
{ }^{1} \text { A win by a team expected to lose by at least } 9 \text { points given the pre-game betting spread. } \\
{ }^{2} \text { The post-game window is a period of three days after the last game was played. } \\
{ }^{3} \text { Equal to } 1 \text { if there are children living in the household with the respondent. }\end{array}$} \\
\hline
\end{tabular}


Table A.5: Placebo Regression: Ordered Logit Coefficients (continued) Dependent Variable: Life Satisfaction

\begin{tabular}{|c|c|c|c|}
\hline \multicolumn{4}{|l|}{ Education dummies (baseline: High school graduate) } \\
\hline Never attended school or only kindergarten & $\begin{array}{l}-.323^{* *} \\
(0.15)\end{array}$ & $\begin{array}{l}-.334^{* *} \\
(0.15)\end{array}$ & $\begin{array}{l}-.333^{* *} \\
(0.15)\end{array}$ \\
\hline Grades 1 - 8 (Elementary) & $\begin{array}{l}-.103^{* * *} \\
(0.03)\end{array}$ & $\begin{array}{l}-.106^{* * *} \\
(0.03)\end{array}$ & $\begin{array}{l}-.137^{* * *} \\
(0.03)\end{array}$ \\
\hline Grades 9 - 11 (Some high school) & $\begin{array}{c}-.04^{*} \\
(0.02)\end{array}$ & $\begin{array}{l}-.041^{*} \\
(0.02)\end{array}$ & $\begin{array}{l}-.063^{* * *} \\
(0.02)\end{array}$ \\
\hline College 1 to 3 years (Some college or technical school) & $\begin{array}{l}.046^{* * *} \\
(0.01)\end{array}$ & $\begin{array}{l}.045^{* * *} \\
(0.01)\end{array}$ & $\begin{array}{l}.045^{* * *} \\
(0.01)\end{array}$ \\
\hline College 4 years or more (College graduate) & $\begin{array}{c}.2^{* * *} \\
(0.01)\end{array}$ & $\begin{array}{l}.198^{* * *} \\
(0.01)\end{array}$ & $\begin{array}{l}.199^{* * *} \\
(0.01)\end{array}$ \\
\hline \multicolumn{4}{|l|}{ Income dummies (baseline: $\$ 35,000$ to under $\$ 50,000$ ) } \\
\hline Annual household income under $\$ 10,000$ & $\begin{array}{l}-.45^{* * *} \\
(0.03)\end{array}$ & $\begin{array}{l}-.453^{* * *} \\
(0.03)\end{array}$ & $\begin{array}{l}-.472^{* * *} \\
(0.03)\end{array}$ \\
\hline Annual household income $\$ 10,000$ to under $\$ 15,000$ & $\begin{array}{l}-.392^{* * *} \\
(0.03)\end{array}$ & $\begin{array}{l}-.394^{* * *} \\
(0.03)\end{array}$ & $\begin{array}{l}-.41^{* * *} \\
(0.03)\end{array}$ \\
\hline Annual household income $\$ 15,000$ to under $\$ 20,000$ & $\begin{array}{l}-.321^{* * *} \\
(0.02)\end{array}$ & $\begin{array}{l}-.324^{* * *} \\
(0.02)\end{array}$ & $\begin{array}{l}-.339^{* * *} \\
(0.02)\end{array}$ \\
\hline Annual household income $\$ 20,000$ to under $\$ 25,000$ & $\begin{array}{l}-.276^{* * *} \\
(0.02)\end{array}$ & $\begin{array}{l}-.276^{* * *} \\
(0.02)\end{array}$ & $\begin{array}{l}-.282^{* * *} \\
(0.02)\end{array}$ \\
\hline Annual household income $\$ 25,000$ to under $\$ 35,000$ & $\begin{array}{l}-.137^{* * *} \\
(0.02)\end{array}$ & $\begin{array}{l}-.137^{* * *} \\
(0.02)\end{array}$ & $\begin{array}{l}-.141^{* * *} \\
(0.02)\end{array}$ \\
\hline Annual household income $\$ 50,000$ to under $\$ 75,000$ & $\begin{array}{l}.16^{* * *} \\
(0.02)\end{array}$ & $\begin{array}{l}.16^{* * *} \\
(0.02)\end{array}$ & $\begin{array}{l}.165^{* * *} \\
(0.02)\end{array}$ \\
\hline Annual household income over $\$ 75,000$ & $\begin{array}{l}.451^{* * *} \\
(0.02)\end{array}$ & $\begin{array}{l}.452^{* * *} \\
(0.02)\end{array}$ & $\begin{array}{l}.462^{* * *} \\
(0.02)\end{array}$ \\
\hline Income info missing & $\begin{array}{l}-.021 \\
(0.02) \\
\end{array}$ & $\begin{array}{l}-.024 \\
(0.02) \\
\end{array}$ & $\begin{array}{l}-.038^{*} \\
(0.02)\end{array}$ \\
\hline \multicolumn{4}{|l|}{ Health proxies } \\
\hline Physically exercising ${ }^{4}$ & $\begin{array}{l}.346^{* * *} \\
(0.01)\end{array}$ & $\begin{array}{l}.346^{* * *} \\
(0.01)\end{array}$ & $\begin{array}{l}.356^{* * *} \\
(0.01)\end{array}$ \\
\hline Limited in activity ${ }^{5}$ & $\begin{array}{l}-.709^{* * *} \\
(0.01)\end{array}$ & $\begin{array}{l}-.713^{* * *} \\
(0.01)\end{array}$ & $\begin{array}{l}-.712^{* * *} \\
(0.01)\end{array}$ \\
\hline Smoking every day & $\begin{array}{l}-.348^{* * *} \\
(0.02)\end{array}$ & $\begin{array}{l}-.348^{* * *} \\
(0.02)\end{array}$ & $\begin{array}{l}-.353^{* * *} \\
(0.02)\end{array}$ \\
\hline Smoking some days & $\begin{array}{l}-.253^{* * *} \\
(0.02)\end{array}$ & $\begin{array}{l}-.253^{* * *} \\
(0.02)\end{array}$ & $\begin{array}{l}-.259^{* * *} \\
(0.02)\end{array}$ \\
\hline Smoking info missing & $\begin{array}{l}.032^{* * *} \\
(0.01) \\
\end{array}$ & $\begin{array}{l}.031^{* * *} \\
(0.01) \\
\end{array}$ & $\begin{array}{l}.028^{* *} \\
(0.01) \\
\end{array}$ \\
\hline cut1 & $\begin{array}{l}-4.72^{* * *} \\
(0.06)\end{array}$ & $\begin{array}{l}-4.8^{* * *} \\
(0.27)\end{array}$ & $\begin{array}{l}-5.02^{* * *} \\
(0.28)\end{array}$ \\
\hline cut2 & $\begin{array}{l}-2.99^{* * *} \\
(0.06)\end{array}$ & $\begin{array}{l}-3.06^{* * *} \\
(0.27)\end{array}$ & $\begin{array}{l}-3.29 * * * \\
(0.28)\end{array}$ \\
\hline cut3 & $\begin{array}{l}.345^{* * *} \\
(0.06)\end{array}$ & $\begin{array}{c}.272 \\
(0.27)\end{array}$ & $\begin{array}{c}.057 \\
(0.28)\end{array}$ \\
\hline Weekly fixed effects & No & Yes & Yes \\
\hline Team-State fixed effects & No & No & Yes \\
\hline Observations & 191350 & 191350 & 191350 \\
\hline
\end{tabular}




\section{B Appendix B: Teams Used in the Analysis}

Table B.1: Teams and States in the Analysis

\begin{tabular}{|c|c|c|}
\hline & Counties & Observations \\
\hline Alabama (Alabama) & 35 & 5831 \\
\hline Arizona (Arizona) & 3 & 2240 \\
\hline Arkansas (Arkansas) & 55 & 6706 \\
\hline Auburn (Alabama) & 3 & 272 \\
\hline Boise State (Idaho) & 10 & 3313 \\
\hline Connecticut (Connecticut) & 7 & 8646 \\
\hline Florida State (Florida) & 5 & 1732 \\
\hline Florida (Florida) & 4 & 1800 \\
\hline Fresno State (California) & 4 & 758 \\
\hline Georgia (Georgia) & 52 & 2184 \\
\hline Illinois (Illinois) & 11 & 531 \\
\hline Iowa State (Iowa) & 2 & 285 \\
\hline Iowa (Iowa) & 36 & 4240 \\
\hline Kansas (Kansas) & 3 & 1919 \\
\hline Kentucky (Kentucky) & 68 & 7008 \\
\hline Louisville (Indiana) & 3 & 270 \\
\hline Louisville (Kentucky) & 3 & 1137 \\
\hline LSU (Louisiana) & 55 & 10273 \\
\hline Maryland (Maryland) & 3 & 3520 \\
\hline Miami (Florida) & 1 & 784 \\
\hline Michigan State (Michigan) & 4 & 617 \\
\hline Michigan (Michigan) & 3 & 729 \\
\hline Mississippi State (Mississippi) & 4 & 554 \\
\hline Missouri (Missouri) & 45 & 4185 \\
\hline North Carolina (North Carolina) & 9 & 1559 \\
\hline Nebraska (Nebraska) & 39 & 12702 \\
\hline Nevada (Nevada) & 6 & 3666 \\
\hline New Mexico (New Mexico) & 2 & 1981 \\
\hline Notre Dame (Indiana) & 7 & 1266 \\
\hline Ohio State (Ohio) & 88 & 15582 \\
\hline Oklahoma State (Oklahoma) & 1 & 205 \\
\hline Oklahoma (Oklahoma) & 49 & 13370 \\
\hline Oregon State (Oregon) & 1 & 239 \\
\hline Oregon (California) & 2 & 79 \\
\hline Oregon (Oregon) & 20 & 9123 \\
\hline Penn State (Pennsylvania) & 41 & 11155 \\
\hline Purdue (Indiana) & 2 & 219 \\
\hline
\end{tabular}

Source: Author's calculation

(Continued on the next page) 
Table B.1: Teams and States in the Analysis (continued)

\begin{tabular}{lcc}
\hline & Counties & Observations \\
\hline South Carolina (South Carolina) & 28 & 7885 \\
Syracuse (New York) & 17 & 1420 \\
Tennessee (Tennessee) & 33 & 2985 \\
Texas A\&M (Texas) & 2 & 68 \\
Texas Tech (Texas) & 4 & 932 \\
Texas (Texas) & 25 & 4063 \\
Utah (Utah) & 3 & 5022 \\
Virginia Tech (Virginia) & 8 & 425 \\
Washington (Washington) & 10 & 14937 \\
West Virginia (West Virginia) & 36 & 4761 \\
Wisconsin (Wisconsin) & 67 & 8909 \\
Wyoming (Wyoming) & 15 & 5017 \\
\hline
\end{tabular}

Source: Author's calculation 


\begin{abstract}
Abstrakt
Každý podzimní týden navštíví fotbalové zápasy v USA miliony divákủ a ještě více jich tento sport sleduje v televizi. Předchozí výzkum ukázal, že nad rámec funkce zábavního průmyslu sportovní události vedou ke změnám nálad u fanoušků, již je sledují. Tato práce zkoumá, zda sport ovlivňuje subjektivní ohodnocení blahobytu občanů. Studie využívá data z dotazníkového šetření Behavioral Risk Factor Surveillance System (BRFSS) a pomocí pořádkového logitu odhaduje efekty výsledků lokálního fotbalového týmu na spokojenost se životem místních obyvatel. Výsledky ukazují, že neočekávané výhry mají na spokojenost se životem pozitivní efekt. Překvapivým výsledkem je zjištění, že neexistuje žádný efekt neočekávaných proher ani jakýchkoliv výsledků, které se na základě očekávání sázkového trhu nedají označit jako přkekvapivé.
\end{abstract}




\section{Working Paper Series}

ISSN 1211-3298

Registration No. (Ministry of Culture): E 19443

Individual researchers, as well as the on-line and printed versions of the CERGE-EI Working Papers (including their dissemination) were supported from institutional support RVO 67985998 from Economics Institute of the CAS, v. v. i.

Specific research support and/or other grants the researchers/publications benefited from are acknowledged at the beginning of the Paper.

(c) Radek Janhuba, 2016

All rights reserved. No part of this publication may be reproduced, stored in a retrieval system or transmitted in any form or by any means, electronic, mechanical or photocopying, recording, or otherwise without the prior permission of the publisher.

Published by

Charles University, Center for Economic Research and Graduate Education (CERGE)

and

Economics Institute of the CAS, v. v. i. (EI)

CERGE-El, Politických vězňů 7, 11121 Prague 1, tel.: +420 224005 153, Czech Republic.

Printed by CERGE-EI, Prague

Subscription: CERGE-EI homepage: http://www.cerge-ei.cz

Phone: + 420224005153

Email: office@cerge-ei.cz

Web: http://www.cerge-ei.cz

Editor: Jan Zápal

The paper is available online at http://www.cerge-ei.cz/publications/working_papers/.

ISBN 978-80-7343-386-4 (Univerzita Karlova, Centrum pro ekonomický výzkum a doktorské studium)

ISBN 978-80-7344-408-2 (Národohospodářský ústav AV ČR, v. v. i.) 
CERGE-EI

P.O.BOX 882

Politických vězňů 7

11121 Praha 1

Czech Republic http://www.cerge-ei.cz 